\title{
Multiple Approaches to a Complete Inventory of Pseudomonas syringae pv. tomato DC3000 Type III Secretion System Effector Proteins
}

\author{
Lisa M. Schechter, ${ }^{1}$ Monica Vencato, ${ }^{1}$ Katy L. Jordan, ${ }^{1}$ Sarah E. Schneider, ${ }^{1}$ David J. Schneider, ${ }^{2}$ and \\ Alan Collmer ${ }^{1}$ \\ ${ }^{1}$ Department of Plant Pathology, Cornell University, Ithaca, NY 14853, U.S.A.; ${ }^{2}$ United States Department of Agriculture- \\ Agricultural Research Service, Ithaca, NY 14853 U.S.A.
}

Submitted 24 January 2006. Accepted 21 June 2006.

Pseudomonas syringae pv. tomato $\mathrm{DC3000}$ is a pathogen of tomato and Arabidopsis that translocates virulence effector proteins into host cells via a type III secretion system (T3SS). Many effector-encoding hypersensitive response and pathogenicity (Hrp) outer protein (hop) genes have been identified previously in DC3000 using bioinformatic methods based on Hrp promoter sequences and characteristic $\mathbf{N}$-terminal amino acid patterns that are associated with T3SS substrates. To approach completion of the Hop/effector inventory in DC3000, 44 additional candidates were tested by the Bordetella pertussis calmodulin-dependent adenylate cyclase (Cya) translocation reporter assay; 10 of the high-probability candidates were confirmed as T3SS substrates. Several previously predicted hop genes were tested for their ability to be expressed in an HrpLdependent manner in culture or to be expressed in planta. The data indicate that DC3000 harbors 53 hop/avr genes and pseudogenes (encoding both injected effectors and T3SS substrates that probably are released to the apoplast); 33 of these genes are likely functional in DC3000, 12 are nonfunctional members of valid Hop families, and 8 are less certain regarding their production at functional levels. Growth of DC3000 in tomato and Arabidopsis Col-0 was not impaired by constitutive expression of repaired versions of two hops that were disrupted naturally by transposable elements or of hop genes that are naturally cryptic. In summary, DC3000 carries a complex mixture of active and inactive hop genes, and the hop genes in $P$. syringae can be identified efficiently by bioinformatic methods; however, a precise inventory of the subset of Hops that are important in pathogenesis awaits more knowledge based on mutant phenotypes and functions within plants.

Effector proteins translocated into host cells by the type III secretion system (T3SS) are collectively essential to the pathogenicity of many plant- and animal-pathogenic bacteria. Despite their importance, identifying the complete collection of effectors produced by any pathogen has proven difficult. The problems complicating type III effector identification include effector redundancies that can mask mutant phenotypes, the lack of

Corresponding author: A. Collmer; E-mail: arc2@cornell.edu; Telephone: +1.607 .255 .7843 ; Fax: +1.607.255.4471.

Current address of L. M. Schechter: Department of Biology, University of Missouri-St. Louis 63121, U.S.A. high-throughput gain-of-function secretion or translocation assays, and the obscure nature of the targeting signals (Sorg et al. 2005). The type III effector inventory of the plant pathogen Pseudomonas syringae pv. tomato DC3000 has attracted particular attention. DC3000 is a model pathogen of the important crop tomato and the model plant Arabidopsis, and the sequence of the DC3000 genome is known (Buell et al. 2003). As a result of multiple studies from several research groups, more than 40 effector genes have been identified so far in DC3000. These studies also have revealed that most of the encoded effectors have $\mathrm{N}$-terminal targeting-associated patterns that can be useful in predicting effectors. The wealth of information on the type III effectors of this one strain invites completion of the inventory and an assessment of the predictive and functional value of the targeting-associated patterns.

The $P$. syringae T3SS is encoded by hypersensitive response and pathogenicity ( $h r p$ ) and hypersensitive response (HR) and conserved $(h r c)$ genes. $P$. syringae type III effectors are designated Hrp outer protein (Hop) and avirulence (Avr) proteins depending on the phenotype by which they were discovered (Lindeberg et al. 2005). All $P$. syringae effectors have a Hop phenotype because they can be secreted or translocated in a T3SS-dependent manner. Some also have an Avr phenotype; when translocated into plant cells carrying a cognate resistance $(R)$ gene, either the effector or its activity is recognized, which results in elicitation of the plant $\mathrm{HR}$ and resistance. It also should be noted that some Hrp proteins, such as the HrpZ1 and HrpW1 harpins encoded within the Hrp pathogenicity island, are thought to operate primarily in the apoplast as potential extracellular "helpers" in T3SS functions. Some of the newly found Hops also may fall into this category, but we will use the terms effector and Hop broadly here to refer generically to proteins that can be translocated into plant cells by the P. syringae T3SS.

Various methods have been used to identify type III effectors in animal and plant pathogens. For example, functional screens have been used to identify effectors in $P$. syringae pv. maculicola and Xanthomonas campestris pv. vesicatoria (Guttman et al. 2002; Roden et al. 2004). Studies of animal pathogen type III effectors include a functional screen for Chlamydia proteins with N-terminal fragments capable of directing type III secretion in Shigella flexneri (Subtil et al. 2005) and a proteomic analysis of proteins secreted by Citrobacter rodentium (Deng et al. 2004). In addition, bioinformatic approaches were used to identify a subset of Salmonella typhimurium effectors that have conserved sequences in the first 150 amino acids and Bordetella effectors that are associated with chaperones (Miao and Miller 2000; Panina et al. 2005). 
AvrPto1 is a particularly well-studied $P$. syringae pv. tomato type III effector. The first avrPto gene was cloned from strain JL1065 on the basis of the avirulence phenotype it conferred on $P$. syringae test strains in tomato cultivars carrying the cognate $P$ to $R$ gene (Ronald et al. 1992). Like a typical $P$. syringae effector, AvrPto1 is preceded by an Hrp box promoter and has an N-terminus with an aliphatic amino acid in position 3 or 4 , no acidic amino acids in the first 12 residues, and a high percentage of Ser (and Thr) in the first 50 residues (Guttman et al. 2002; Petnicki-Ocwieja et al. 2002). AvrPto1 is a useful positive control for genomewide searches for type III effector genes in DC3000, and it has been found in an in planta expression technology (IPET) screen for genes induced during infection (Boch et al. 2002), in a reporter transposon screen for genes activated by the HrpL alternative sigma factor (Fouts et al. 2002), in searches for genes preceded by Hrp box sequences (Fouts et al. 2002; Guttman et al. 2002; Zwiesler-Vollick et al. 2002), in searches for genes predicting type III targeting signals (Guttman et al. 2002; Petnicki-Ocwieja et al. 2002), in a differential fluorescence induction (DFI) screen for genes activated by HrpL (Chang et al. 2005), and in a whole-genome microarray analysis (Ferreira et al. 2006). Each of these studies identified variously overlapping sets of effector candidates in addition to AvrPto1. The differences in these sets relate to ambiguities in Hrp promoter sequences and type III targeting-associated patterns, as well as differences in observed levels of expression and translocation.

Despite the enormous effort to identify effectors in DC3000, several questions remain unanswered. Does DC3000 produce other classes of type III effectors that, unlike AvrPto1, are not associated with Hrp promoters or the recognized targeting-associated patterns? Are all DC3000 type III effectors that pass translocation tests when expressed from vector promoters produced in planta from native promoters? Given the importance of both gene acquisition and gene loss in the evolution of virulence, does the disruption of certain effector genes by transposon insertions allow DC3000 to infect its hosts tomato and Arabidopsis? Finally, given the role of DC3000 as a reference strain, what is the "complete" inventory of bona fide type III effector genes in DC3000, including those that are silent, nonfunctional, or disrupted by transposable elements?

In this article, we address these questions through multiple approaches. First, we tested 44 possible type III effector (Hop) candidates for their ability to be translocated by DC3000 using the quantitative Bordetella pertussis calmodulin-dependent adenylate cyclase (Cya) reporter assay. Importantly, many of these candidates were chosen by a variety of criteria other than Hrp promoters and targeting-associated patterns. Second, we used real-time polymerase chain reaction (PCR) and in planta expression technology to assess the expression of several known hop effector genes. Third, we assayed the virulence of DC3000 expressing several normally cryptic or disrupted effector genes.

\section{RESULTS}

\section{Comprehensive identification}

of candidate hop genes in $P$. syringae pv. tomato DC3000.

The criteria depicted in Figure 1 were used to identify 44 additional candidate hop genes for T3SS-dependent translocation testing. In general, these criteria addressed two broad categories of candidates: those with a high probability for being effectors but which awaited testing, and lower-probability candidates that could represent novel classes of effectors. Several high-probability candidates were identified on the basis of their association with Hrp boxes as previously defined and then refined based on microarray analysis (Ferreira et al. 2006;
Fouts et al. 2002). The locations of these Hrp promoters and candidate hop genes in the DC3000 genome can be visualized using the Artemis genome browser developed by the Sanger Institute. Guidance for the use of the browser and associated data files can be found at the Pseudomonas-Plant Interaction website. Other high-probability candidates were identified on the basis of the three major features of $P$. syringae type III targeting-associated patterns. That is, the N-terminal 50 amino acids contain $>10 \%$ serine; position 3 or 4 contains Ile, Leu, Val, or Pro; and there is no acidic amino acid in the first 12 positions (Guttman et al. 2002; Petnicki-Ocwieja et al. 2002). To identify a possible novel class of effectors, we tested several genes that were proximal to known hop genes because many hop genes are clustered in pathogenicity islands or islets on the DC3000 genome. We also tested several genes encoding proteins that could have activity in eukaryotic signal transduction pathways or with plant cell wall substrates, such as pectate and cellulose. We did not test DC3000 genes that had $<100$ codons or that had homologs in the nonpathogen P. putida KT2440. The candidate genes were cloned by PCR into the pENTRSD/D-TOPO vector (Invitrogen, Carlsbad, CA, U.S.A.) and then recombined into Gateway destination vector pCPP3234 (Schechter et al. 2004). The resultant constructs were confirmed by immunoblot analysis to produce the predicted candidateCya fusions in DC3000 before being assayed for translocation (data not shown).

\section{Candidate Hop proteins were tested for their ability} to be translocated into plant cells by using the Cya reporter.

Candidates were tested with the Cya reporter for their ability to be translocated in a T3SS-dependent manner into Nicotiana benthamiana by $P$. syringae pv. tomato DC3000 (Schechter et al. 2004).

The translocation of type III effectors carrying C-terminal fusions with Cya can be monitored by the calmodulin-dependent production of cyclic AMP (cAMP) within eukaryote cells

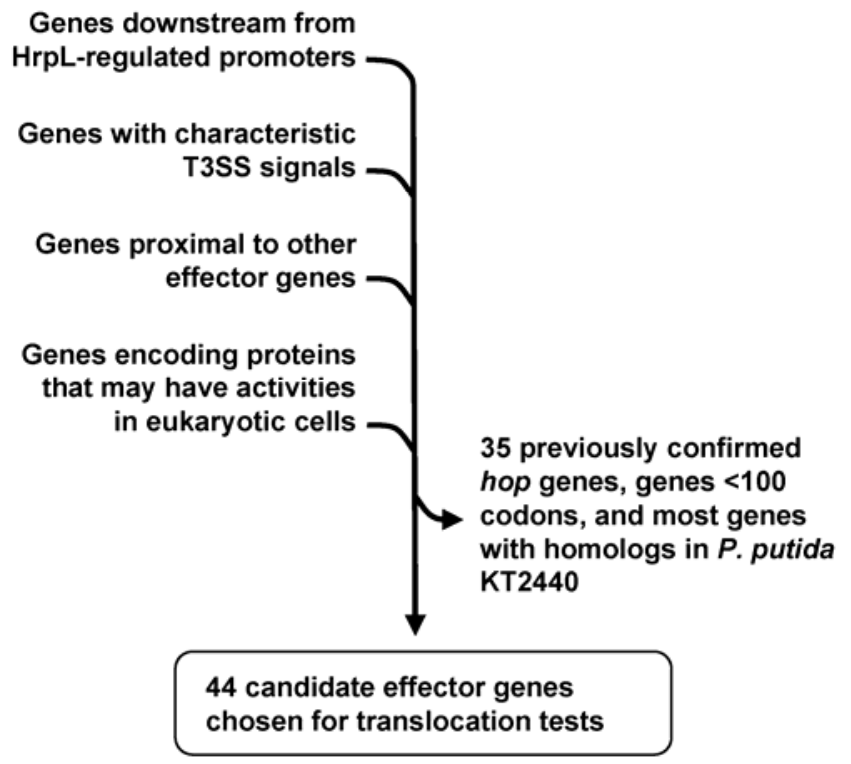

Fig. 1. Strategy for genomewide identification of candidate effector genes in Pseudomonas syringae pv. tomato DC3000. The DC3000 genome was scanned for genes that possess one or more of the four features listed on the left side of the figure and described further in the text. From this list, genes described on the right side of the figure were excluded from further investigation. Effector candidates encoded by the 44 remaining genes were tested for translocation into plant cells. Hrp $=$ hypersensitive response and pathogenicity, T3SS = type III secretion system, and Hop = Hrp outer protein. 
(Casper-Lindley et al. 2002; Sory and Cornelis 1994). The Cya translocation reporter assay yields quantitative data on translocation efficiencies, and the resulting comparative data complements other effector surveys that used the AvrRpt $2_{(81-255)}$ translocation reporter (Chang et al. 2005; Vinatzer et al. 2005). Candidate genes were expressed from the tac promoter in pCPP3234 to provide adequate expression for definitive translocation tests and to permit comparison of the translocation efficiencies of equally expressed proteins. It also is important to note that Cya was fused to the full-length Hop candidate in most cases. However, in certain cases, the candidates were so large (>900 amino acids) that we had to make fusions with $\mathrm{C}$ terminally truncated versions of these proteins (Tables 1 and 2).

\section{Most of the high-probability Hop candidates were confirmed to be translocated in a T3SS-dependent manner.}

Ten of the high-probability candidates were translocated into plant cells (Fig. 2). Table 1 indicates whether they have any homologs or domains predictive of function, as well as the status of each Hop regarding Hrp regulation and type III targeting-associated patterns. The translocation of PSPTO0907 was weak compared with the others, but it was consistently higher with DC3000 than with the $\Delta h r p / h r c$ mutant CUCPB5114. While this work was in preparation, several of these Hops (HopR1, HopY1, HopAH1, HopAH2-1, HopAI1, and HopT1-2) were shown to travel the Hrp T3SS by other methods (Chang et al. 2005; Guo et al. 2005; Vinatzer et al. 2005). However, four of the confirmed Hops in Table 1 had not been tested before. PSPTO4592 encodes a member of the HopO family and, thus, it already had been named HopO1-3' (Lindeberg et al. 2005). Although the C-terminus of HopO1-3' is truncated due to a premature stop codon, our results show that the $\mathrm{N}$-terminal region of this protein allows the delivery of the Cya reporter in plant cells. PSPTO3293 encodes a protein closely related to HopAH2. Therefore, we renamed PSPTO3292 HopAH2-1 and will call PSPTO3293 HopAH2-2. PSPTO0474 had not been identified previously as a T3SS substrate, and we named it HopAS1'. HopAS1' represents a 279amino acid frameshift truncation of a much larger effector that is activated by $\mathrm{HrpL}$ and translocated by $P$. syringae pv. phaseolicola 1448A (Vencato et al. 2006). PSPTO0907 also is translocated by DC3000; however, because it is not produced in an HrpL-dependent manner, we cannot designate it as a Hop unless one or more compliant Hop homologs are found in other strains of $P$. syringae (Lindeberg et al. 2005). Interestingly, 3 of the 10 Hop proteins validated as T3SS substrates in this study contained only two of three primary patterns used to predict T3SS substrates (Guttman et al. 2002; Petnicki-Ocwieja et al. 2002; Schechter et al. 2004), and 2 contained only one of the patterns. As shown below, the hop genes encoding these proteins were not activated by HrpL.

\section{Three DC3000 Hop candidates with functional hop homologs were found not to be translocated.}

The candidates presented in Table 2 were judged as not being translocated because they did not allow the accumulation

Table 1. Features of Hop proteins confirmed to be translocated into plant cells by the DC3000 type III secretion system in this study

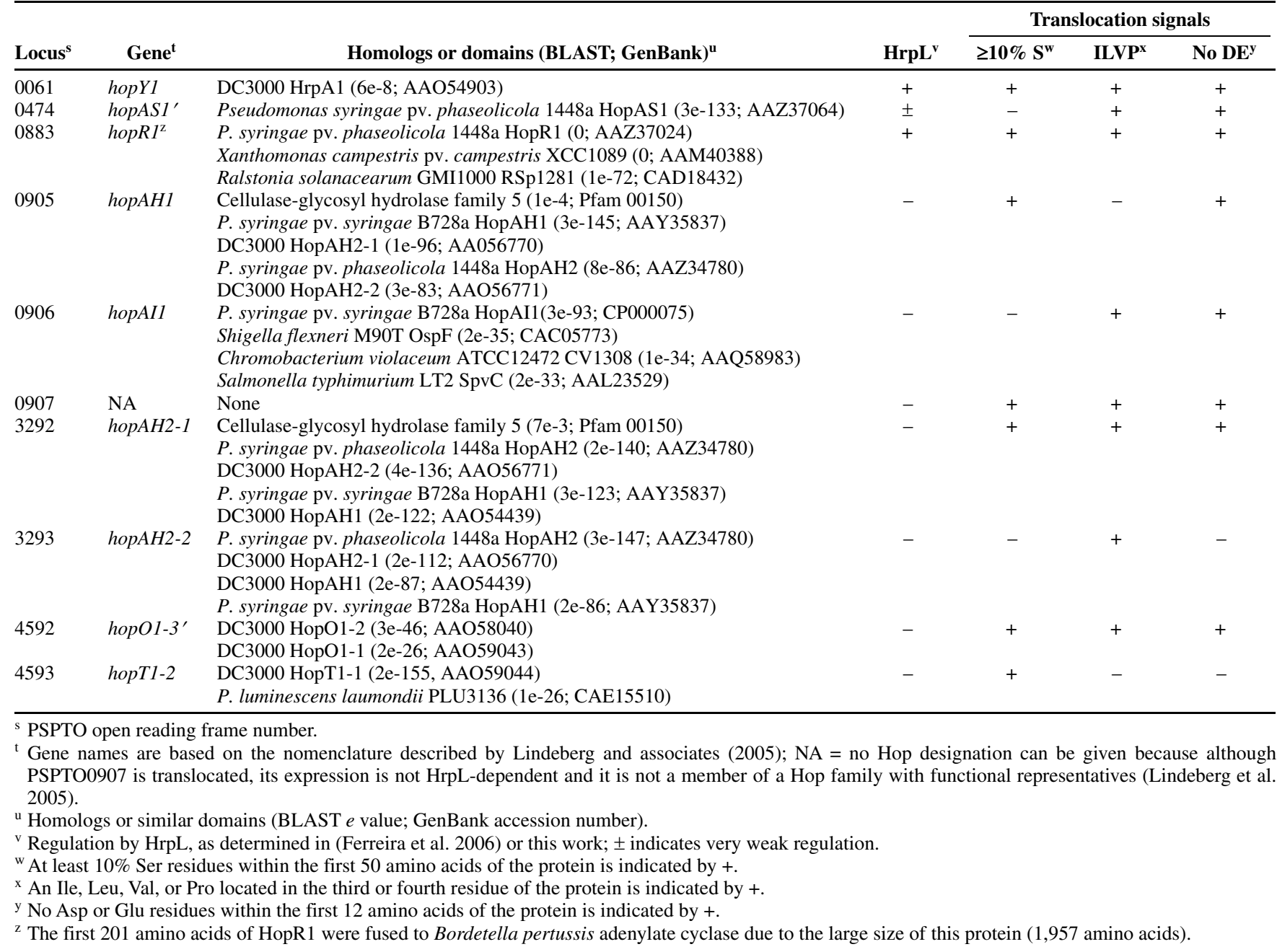


of more than 5 pmol cAMP per microgram of protein in plants (data not shown).Three candidates, HopT2, HopQ1-2, and HopAC1, show similarity to confirmed Hops, HopT1-1, HopQ1-1, and HopB1, respectively. It is important to note that each of these inactive homologs is not similar to its respective confirmed Hop in the N-terminal region that is required for targeting to the T3SS. In fact, the hopACl gene in DC3000 appears to be disrupted by a transposable element, because a much larger intact version of this gene is present in $P$. syringae pv. syringae B728a (Greenberg and Vinatzer 2003). However, the full-length HopAC1 from B728a also is not translocated into plant cells (B. Vinatzer, personal communication).

\section{Genes encoding several of the newly confirmed Hop proteins in DC3000 are not activated by HrpL.}

Eight of the genes encoding proteins shown to be translocated in this study were not observed to be regulated by HrpL in a whole-genome microarray analysis (Ferreira et al. 2006). We performed real-time PCR analyses of these genes in wildtype DC3000 and $\Delta h r p L$ mutant UNL134-1 grown in Hrpinducing minimal medium to further test whether these genes are $\mathrm{HrpL}$ responsive (Fig. 3). Two of these genes, hopRl and hopAS1', are located downstream from Hrp boxes. We found that hopRl expression was activated by HrpL, but its induction was weak compared with that of $h r c S$, a known HrpL-regulated gene (Fig. 3). The hopAS1' gene also was very weakly regulated by HrpL. The hrpL deletion did not affect the expression of the hopAH1, hopO1-3', hopT1-2, or PSPTO0907 genes. This is not surprising, because these genes appear to be located in operons that are disrupted by transposable elements. The hopAH2-1 and hopAH2-2 genes, which are not located downstream from $h r p$ boxes, also were not found to be regulated by HrpL.

\section{Genes encoding several of the newly confirmed Hop proteins do not appear to be expressed by DC3000 in planta.}

We next asked whether selected genes encoding newly confirmed Hop proteins that were activated by HrpL only weakly or not at all were nevertheless expressed in planta. We employed a directed version of the IPET (in vivo expression technology) strategy, which is based on the finding that a T3SS-deficient

Table 2. Hop candidates found not to be translocated into plant cells by the DC3000 type III secretion system in this study

\begin{tabular}{|c|c|c|c|c|c|}
\hline \multirow[b]{2}{*}{ Locus (gene) ${ }^{\mathbf{q}}$} & \multirow[b]{2}{*}{ Homologs or domains (BLAST; GenBank) ${ }^{r}$} & \multirow[b]{2}{*}{$\operatorname{HrpL}^{\mathrm{s}}$} & \multicolumn{3}{|c|}{ Translocation signals } \\
\hline & & & $\geq 10 \% \mathrm{~S}^{\mathrm{t}}$ & ILVP $^{\mathrm{u}}$ & No $\mathbf{D E}^{\mathrm{V}}$ \\
\hline 0400 & Glycosyl hydrolase family 18 (3e-11, Pfam 00704) & $-{ }^{\mathrm{w}}$ & - & + & + \\
\hline 0471 & Putative nucleotidyltransferase DUF294 (3e-63; Pfam 03445) & - & + & + & + \\
\hline $0473^{x}$ & Xanthomonas axonopodis citri 306 XAC2009 (1e-6; AAM36871) & - & - & + & + \\
\hline 0475 & Conserved hypothetical protein of unknown function ${ }^{z}$ & - & + & + & + \\
\hline 0848 & Conserved hypothetical protein of unknown function ${ }^{\mathrm{z}}$ & - & + & - & + \\
\hline 0849 & Conserved hypothetical protein of unknown function ${ }^{\mathrm{z}}$ & - & + & + & + \\
\hline 0869 & Conserved hypothetical protein of unknown function ${ }^{\mathrm{z}}$ & $-{ }^{\mathrm{w}}$ & - & + & + \\
\hline 1409 & Conserved hypothetical protein of unknown function ${ }^{\mathrm{z}}$ & $-{ }^{\mathrm{w}}$ & - & - & + \\
\hline 1657 & Pseudomonas syringae tomato DC3000 PSPTO0021 (2e-161; AAO53577) & - & + & - & - \\
\hline 2870 & Conserved hypothetical protein of unknown function ${ }^{\mathrm{z}}$ & - & - & - & - \\
\hline $2871^{x}$ & Conserved hypothetical protein of unknown function ${ }^{\mathrm{z}}$ & - & - & + & - \\
\hline 2873 & Conserved hypothetical protein of unknown function ${ }^{\mathrm{z}}$ & - & - & + & + \\
\hline 2874 & P. aeruginosa PAK PpkA (7e-99; AAD03499) & - & - & + & + \\
\hline 2877 & Conserved hypothetical protein of unknown function ${ }^{\mathrm{z}}$ & - & - & - & + \\
\hline 2878 & Conserved hypothetical protein of unknown function ${ }^{\mathrm{z}}$ & - & + & + & + \\
\hline 2880 & Von Willebrand factor type A domain (1e-8; cd01456) & - & + & + & - \\
\hline 3120 & Cof hydrolases of the HAD superfamily (4e-47; COG0561) & $-{ }^{\mathrm{w}}$ & + & + & - \\
\hline 3483 & P. fluorescens PfO-1 Pfl0152 (3e-49; ABA71896) & $-{ }^{\mathrm{w}}$ & + & + & - \\
\hline 3534 & Glycosyl hydrolase family 5 (8e-7; Pfam00150) & - & - & - & + \\
\hline $4340^{\mathrm{f}}$ & P. luminescens insecticidal toxin TccC (3e-126; AAO17196) & - & + & + & + \\
\hline $4342^{x}$ & P. luminescens insecticidal toxin TccB (9e-152; AAL18472) & - & - & - & - \\
\hline $4343^{x}$ & P. luminescens insecticidal toxin TcdB (0; AAO17202) & - & + & - & - \\
\hline $4344^{x}$ & P. luminescens insecticidal toxin TccC (1e-118; AAO17204) & - & - & - & - \\
\hline 4590 (hopT2) & DC3000 HopT1-2 (5e-25; AAO58039) & - & + & - & + \\
\hline $4699^{\mathrm{x}}$ & Non-ribosomal peptide synthetase module (1e-155; COG1020) & $-{ }^{\mathrm{w}}$ & + & + & + \\
\hline 4732 (hopQ1-2) & DC3000 HopQ1 (2e-56; AAO54411) & + & + & + & - \\
\hline 4733 & Ralstonia metallidurans CH34 RMe0230 (5e-7; CAI11198) & $-{ }^{\mathrm{w}}$ & - & + & + \\
\hline 4956 & Conserved hypothetical protein of unknown function ${ }^{z}$ & $-{ }^{\mathrm{w}}$ & + & - & + \\
\hline $4996(\text { hopAC1 })^{\mathrm{x}}$ & DC3000 HopB1 (6e-16; AAO54928) & - & + & - & - \\
\hline 5355 & P. syringae pv. phaseolicola $\mathrm{PSPPH} 4936$ (8e-65; AAZ33056) & - & - & + & - \\
\hline 5416 & Protein kinase domain (8e-31; Pfam 00069) & - & - & + & - \\
\hline 5417 & Serine/threonine phosphatases family $2 \mathrm{C}$ (2e-34; cd00143) & - & - & + & + \\
\hline 5432 & Conserved hypothetical protein of unknown function ${ }^{\mathrm{z}}$ & - & + & + & + \\
\hline B0005 & Phosphoesterase family (5e-44; Pfam 04185) & + & + & - & - \\
\hline
\end{tabular}

q PSPTO open reading frame (ORF) number (gene name).

${ }^{\mathrm{r}}$ Homologs or similar domains (BLAST $e$ value; GenBank accession number).

s Regulation by HrpL, as determined by Ferreira and associates (2006) or this work; \pm indicates very weak HrpL-dependent expression.

${ }^{t}$ At least $10 \%$ serine residues within the first 50 amino acids of the protein is indicated by + .

u An Ile, Leu, Val, or Pro located in the third or fourth residue of the protein is indicated by + .

${ }^{v}$ No Asp or Glu residues within the first 12 amino acids of the protein is indicated by + .

${ }^{\mathrm{w}}$ Gene is downstream from an hrp box but no regulation by HrpL was detectable (Ferreira et al. 2006).

${ }^{\mathrm{x}}$ Due to the large size of these proteins, the following number of N-terminal amino acids were fused to Bordetella pertussis adenylate cyclase: 207 of PSPTO0473, 214 of PSPTO2871, 200 of PSPTO4340, 103 of PSPTO4342, 100 of PSPTO4343, 101 of PSPTO4344, 204 of PSPTO4699, and 400 of PSPTO4996.

y This ORF encodes a protein that is homologous to the C-terminal region of HopAS1 in P. syringae pv. phaseolicola 1448a.

${ }^{\mathrm{z}}$ ORFs that were highly similar to more than two bacterial proteins in GenBank. 


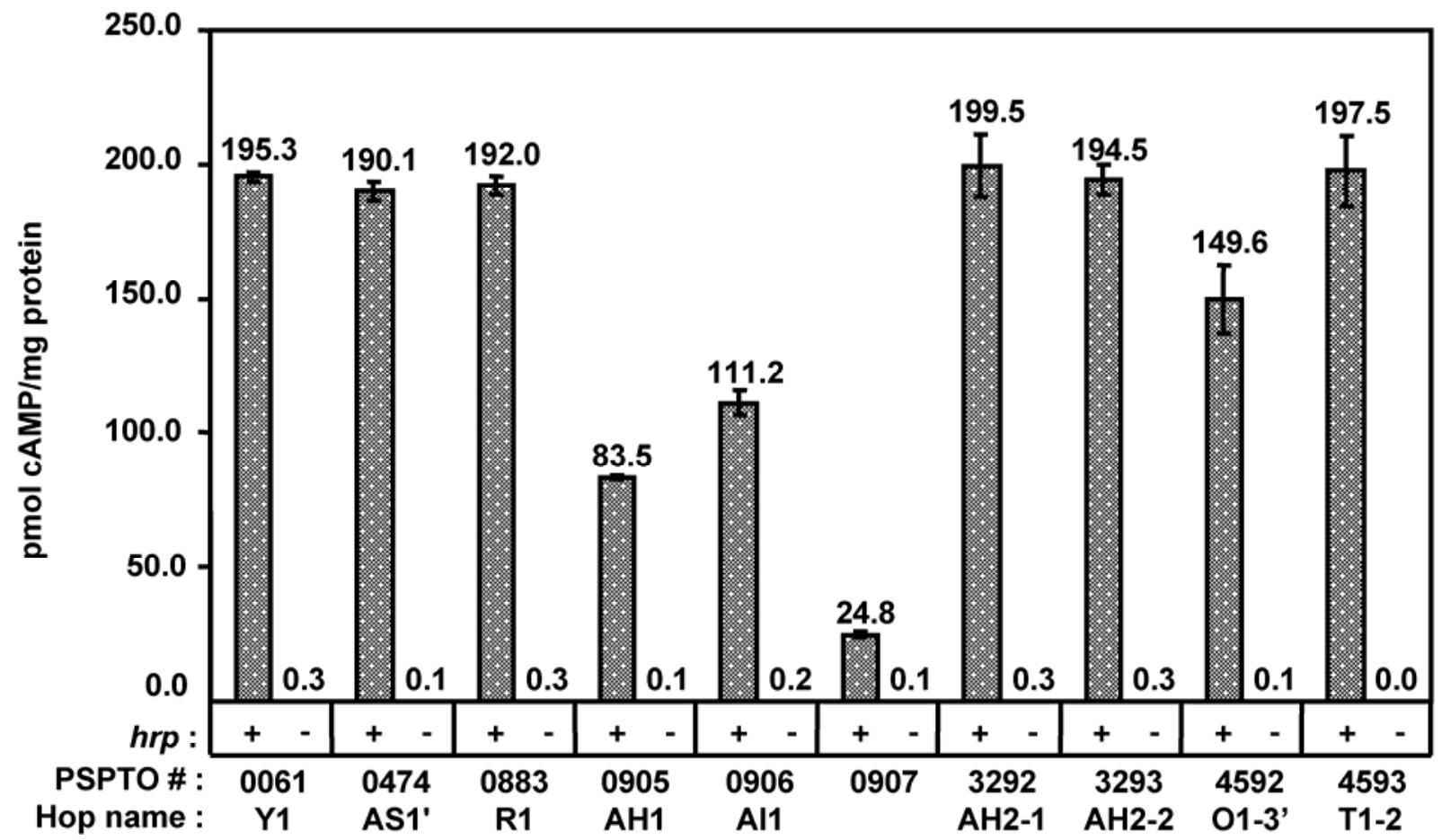

Fig. 2. Translocation of candidate effectors based on increased cyclic AMP (cAMP) levels in Nicotiana benthamiana following inoculation with DC3000 strains expressing calmodulin-dependent adenylate cyclase (Cya) hybrid proteins. N. benthamiana leaves were inoculated with either DC3000 or CUCPB5114 (DC3000 $\Delta h r p K-h r p R:: \Omega \mathrm{Cm}$ ) bacteria expressing the indicated Cya hybrid proteins from the vector tac promoter. The proteins that were N-terminally fused to Cya are denoted by both their open reading frame number and hypersensitive response and pathogenicity (Hrp) outer protein (Hop) name. Leaf samples were collected with a $0.8-\mathrm{cm}$-diameter cork borer $7 \mathrm{~h}$ post inoculation. cAMP and protein levels were quantified in duplicate and averaged for each sample. The average amount of cAMP per microgram of protein for each sample is indicated above the appropriate bar in the graph, and standard deviations are indicated by error bars. Repeated experiments yielded similar relative levels of cAMP production for each of the strains tested.

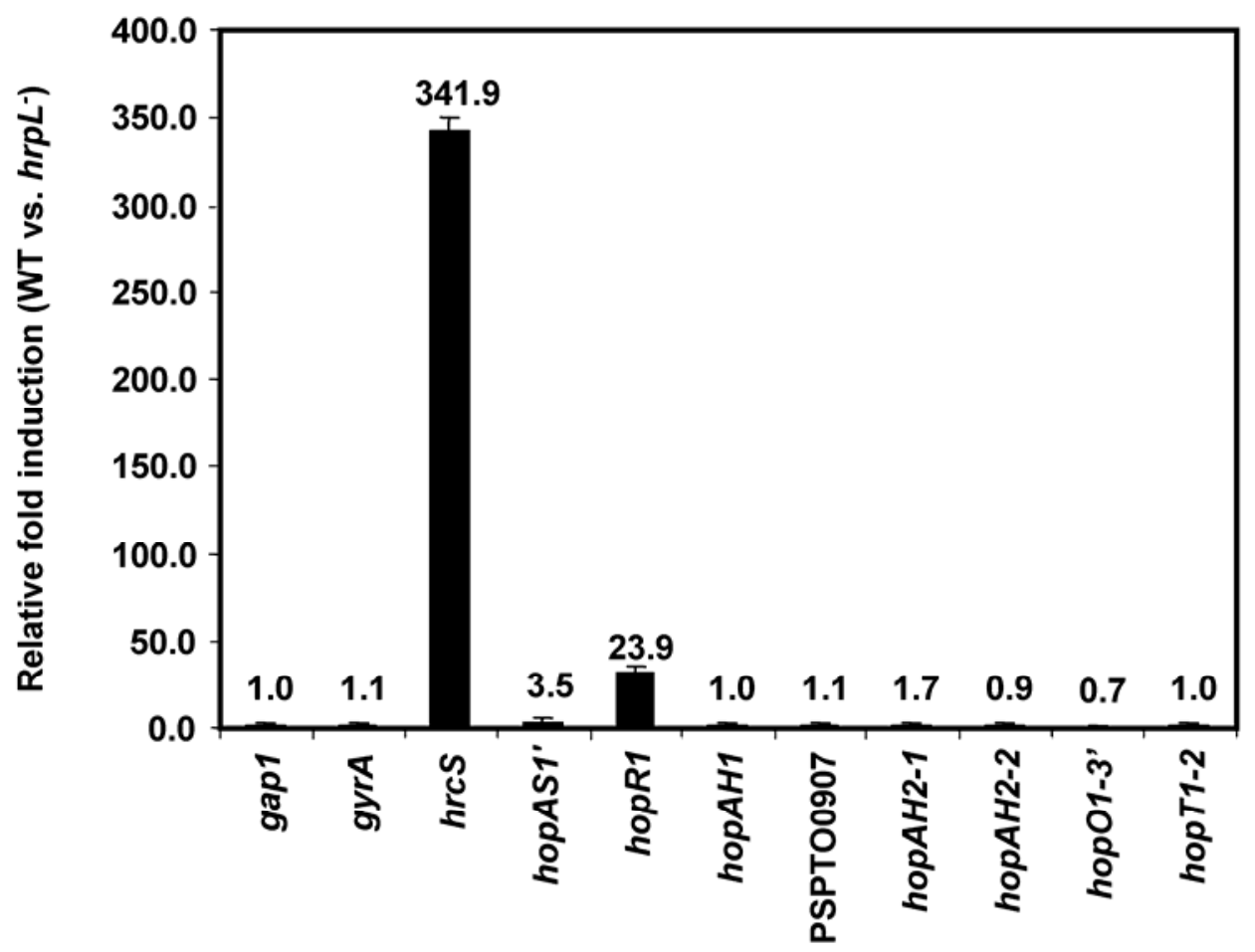

Fig. 3. Analysis of HrpL regulation of hypersensitive response and pathogenicity (Hrp) outer protein (hop) gene expression in Pseudomonas syringae pv. tomato DC3000 by real-time polymerase chain reaction (PCR). Quantitative SYBR green-based real-time PCR was performed on cDNA prepared from either DC3000 or UNL134-1 (DC3000 $\Delta h r p L$ ) grown in $h r p$-derepressing fructose minimal medium, as described elsewhere (Vencato et al. 2006). The relative fold induction of each gene by HrpL was determined by the standard curve method after normalization to either gapl or gyrA, two housekeeping genes that served as endogenous controls. The numbers reported are the average and standard deviation of values obtained by two different normalization methods in three separate experiments, as described (Vencato et al. 2006). 
DC3000 hrcC mutant is unable to cause disease or elicit the $\mathrm{HR}$ unless $\mathrm{HrcC}$ production is restored through a $\mathrm{hrcC}$ gene in trans expressed from a test promoter that is active in planta (Boch et al. 2002). DNA fragments containing the hopRl, hopAS1', hopAH2-1, and hopAH2-2 promoters were cloned into the kanamycin-resistant pIPET plasmid upstream of the promoterless $h r c C$ gene, and these plasmids were transferred into TLR1 (DC3000 $\Delta h r c C:: \mathrm{Sp}^{\mathrm{R}}$ ). Because pIPET cannot replicate in $P$. syringae, the plasmid must recombine into the chromosome at sites homologous to the cloned promoter fragment to confer kanamycin resistance. If these promoters are active in planta, they will drive expression of the promoterless $h r c C$ gene in pIPET, which would complement the deletion of the native $h r c C$ in TLR1. As a negative control, plants were inoculated with JB201, a TLR1 strain that contains pIPET inserted downstream from the reverse orientation of the avrPtol promoter. As a positive control, plants were inoculated with JB200, a TLR1 strain that contains pIPET inserted in the forward orientation downstream from the avrPtol promoter. We observed elicitation of the HR in each of 12 tests involving JB200 and with CUCPB5431, which contains pIPET downstream of the hopRl promoter. However, the HR produced by CUCPB5431was delayed by approximately $24 \mathrm{~h}$ compared with JB200, which may be due to the weak activation of hopRl by HrpL. We did not observe an HR in repeated tests involving the hopAS', hopAH2-1, and hopAH2-2 promoters.

\section{Growth in tomato and Arabidopsis}

of $P$. syringae pv. tomato DC3000 is not impaired by constitutively expressing normally cryptic or disrupted hop genes.

It has been suggested that diverse combinations of effectors in different $P$. syringae pathovars may be responsible for the di- verse host ranges of these strains (Greenberg and Vinatzer 2003). The presence in DC3000 of several cryptic or disrupted hop genes raises the possibility that, if these genes were functional, they would cause DC3000 to become avirulent in hosts tomato and Arabidopsis. To test this possibility, we constructed derivatives of DC3000 and $\Delta h r p / h r c$ mutant CUCPB5114 carrying CPP3234 expressing Hop-Cya fusions of the test effectors from the vector tac promoter. Two of the effector genes that were tested, hopAG::ISPssy and hopS1::ISPssy, were repaired using PCR to remove disrupting transposon sequences; and five others, hopAH1, hopAI1, hopO1-3', hopT1-2, and PSPTO0907 appeared unlikely to be expressed in planta. Tomato cv. Moneymaker plants were inoculated by dipping with DC3000 strains that contained plasmids expressing various Hop-Cya fusion proteins that had been shown to be delivered into plants (data not shown; Fig. 2). As a control, plants also were infected with DC3000 expressing AvrPto-Cya, which does not cause the HR in Moneymaker tomato. None of the Hop-Cya fusion proteins reduced the growth of DC3000 in tomato plants at either 2 or 5 days post inoculation (Fig. 4). Similar results were obtained in an experiment using Arabidopsis Col-0 plants as the host (data not shown). A slight increase in the growth of DC3000 expressing HopAH1 can be seen in Figure 4; however, the increase is not statistically significant based on a $t$ test (where equal variances were not assumed) and on a repeated measures analysis of variance test. Furthermore, there was no increased growth of this strain in Arabidopsis. Bacterial colonies that were recovered from plants 3 days post infection were patched on selective medium to examine whether they maintained the plasmid expressing the Hop-Cya fusion protein. For each strain, 80 to $100 \%$ of the colonies had maintained the plasmid. In summary, none of the test effectors caused DC3000 to become avirulent on hosts tomato and Arabidopsis.

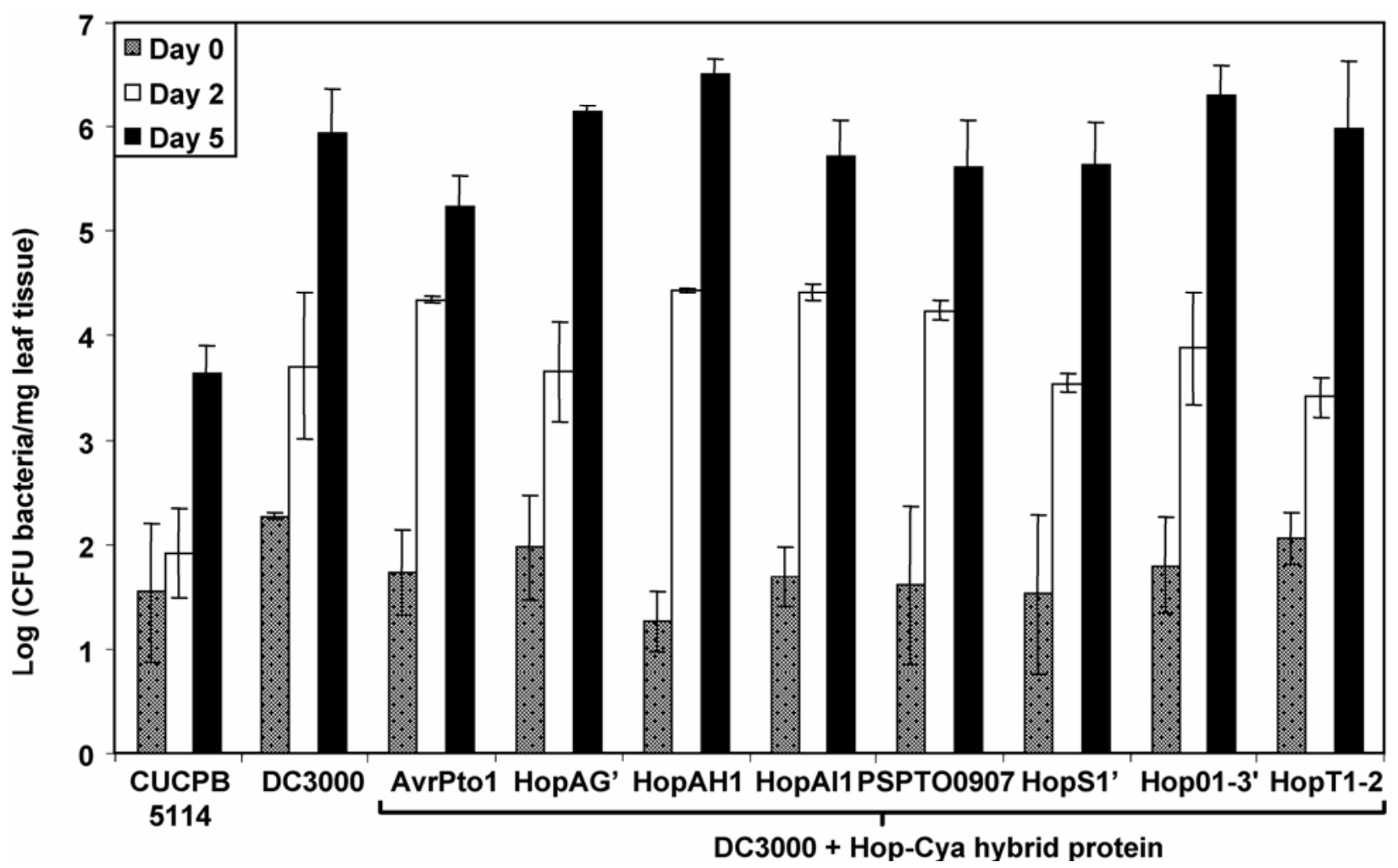

Fig. 4. Growth of Pseudomonas syringae pv. tomato DC3000 strains expressing hypersensitive response and pathogenicity (Hrp) outer protein (Hop) calmodulin-dependent adenylate cyclase (Cya) fusion proteins in tomato. Tomato (cv. Moneymaker) plants were inoculated by dipping in CUCPB5114 (DC3000 $\Delta h r p K-h r p R:: \Omega C m$ ), wild-type DC3000, or DC3000 strains at $5 \times 10^{6} \mathrm{CFU} \mathrm{m}^{-1}$ expressing the indicated Hop-Cya fusion proteins. The number of bacteria per milligram of leaf tissue was determined as described in the Materials and Methods at the indicated number of days post infection. Each value is the mean of four data points, and error bars indicate the standard deviations. 


\section{DISCUSSION}

We have used multiple approaches aimed at determining the complete inventory of effector genes in P. syringae pv. tomato DC3000. These approaches represent the culmination of a chain of studies in which we used bioinformatic and experimental techniques to find and verify type III effectors in this model pathogen. Below, we will discuss several aspects of the DC3000 effector inventory: i) the strengths and weaknesses of different approaches to effector identification in $P$. syringae, ii) the existence of nonfunctional effectors, and iii) the current status of the inventory. A summary of the current DC3000 effector inventory, with the features discussed below highlighted, is presented in Table 3.

\section{Evaluation of the candidate gene approach for identifying type III effectors in $P$. syringae pv. tomato $\mathrm{DC} 3000$.}

Our chain of studies has used a three-step method to identify type III effectors in DC3000. First, Hrp promoter sequences with a high probability of functionality were identified by a hidden Markov model and other criteria (Ferreira et al. 2006; Fouts et al. 2002). Second, candidate effector genes downstream of such promoters were predicted based on targeting-associated amino acid patterns (Petnicki-Ocwieja et al. 2002). Third, the ability of candidate genes to produce type III substrates was tested by translocation or secretion assays employing a vector tac promoter whose strength in pseudomonads approximates that of well-expressed Hrp promoters (Schechter et al. 2004). The present study completes the testing of candidates generated by the first two steps. Identification of the effector inventory in DC3000 also has been advanced by a candidate gene approach similarly taken by J. Greenberg, D. Guttman, B. Vintazer, and their colleagues (Greenberg and Vinatzer 2003; Guttman et al. 2002; Vinatzer et al. 2005). Importantly, the success of these bioinformatics-based approaches now can be gauged by comparison with the recent near-saturation DFI screen and translocation tests of Chang and associates (2005) (Table 3).

The DFI-based study identified 25 DC3000 proteins that, when fused to $\triangle 79 \mathrm{AvrRpt} 2$, reliably elicited an RPS2-dependent $\mathrm{HR}$ in Arabidopsis that is indicative of translocation. Twenty of these proteins were identified through the DFI screen itself, but all of them had been reported previously in bioinformatic-driven studies (Guttman et al. 2002; Petnicki-Ocwieja et al. 2002;

Table 3. Inventory of genes encoding Hop/effector proteins in Pseudomonas syringae pv. tomato DC3000

\begin{tabular}{|c|c|c|c|c|c|c|}
\hline \multirow[b]{2}{*}{ Locus $^{t}$} & \multirow[b]{2}{*}{ Name $^{u}$} & \multirow[b]{2}{*}{ Expression $^{\mathbf{v}}$} & \multirow[b]{2}{*}{ T3SS $^{\mathbf{w}}$} & \multicolumn{2}{|c|}{ Secretion/translocation } & \multirow[b]{2}{*}{ Phenotype observed $^{z}$} \\
\hline & & & & Heterologous promoter ${ }^{x}$ & Native promoter ${ }^{y}$ & \\
\hline 0044 & hopK1 & $\mathbf{D}, \mathbf{M}$ & 1,2,3; H & $\mathbf{a b}$ & + & \\
\hline 0061 & hopY1 & $\mathrm{D}, \mathrm{M}, \mathrm{T}$ & $1,2,3 ; \mathrm{H}$ & cd & + & \\
\hline 0474 & hopAS1' & M & 2,$3 ; \mathrm{H}$ & $\mathrm{c}$ & NT & \\
\hline 0501 & hopU1 & Alfano, unpublished & 1,2,3; H & $\mathbf{a}$ & - & Alfano, unpublished \\
\hline 0502 & hopF2 & $\mathbf{D}, \mathbf{M}$ & $1,2,3 ; C ; H$ & ef & + & Jamir et al. 2004 \\
\hline 0588 & hopH1 & $\mathbf{D}, \mathbf{M}$ & $1,2,3$ & $\mathbf{a}$ & + & \\
\hline 0589 & hopCl & $\mathrm{D}, \mathrm{M}, \mathrm{T}$ & $1,2,3 ; \mathrm{H}$ & $\mathbf{a b}$ & + & \\
\hline 0852 & һорАJ1 & $\mathrm{D}, \mathrm{M}, \mathrm{T}$ & $1,2,3 ; \mathrm{H}$ & NT & - & \\
\hline 0876 & hopD1 & $\mathbf{D}, \mathbf{M}$ & $1,2,3 ; \mathrm{H}$ & $\mathbf{a}$ & + & \\
\hline 0877 & hop $Q 1-1$ & $\mathbf{D}, \mathbf{M}$ & $1,2,3$ & bd & + & \\
\hline 0883 & hopRI & D, M, T & $1,2,3$ & cd & NT & \\
\hline$\wedge 0901$ & hopAG::ISPssy & $\mathrm{D}$ & $1,2,3 ; \mathrm{H}$ & $\mathrm{b}$ & - & \\
\hline$\wedge 0905$ & hорAH1* & $\mathrm{NE}$ & 1,$3 ; \mathrm{H}$ & $\mathrm{cd}$ & NT & \\
\hline$\wedge 0906$ & hopAI1* & $\mathrm{NE}$ & 2,3 & $\mathrm{~cd}$ & NT & \\
\hline$\wedge 0907$ & $-*$ & $\mathrm{NE}$ & $1,2,3$ & $\mathrm{c}$ & NT & \\
\hline 1022 & hорАМ1-1 & D, M, I & 1,3; H & NT & + & Jamir et al. 2004 \\
\hline$\wedge 1179$ & hopJ1 & - , no Hrp box & $1,2,3$ & N-terminal fragment & - & \\
\hline 1370 & hopN1 & $\mathbf{D}, \mathbf{M}, \mathbf{T}, \mathbf{I}$ & $1,2,3 ; C$ & h & + & \\
\hline 1372 & hорАА 1-1 & $\mathbf{D}, \mathbf{M}, \mathbf{T}$ & $1,2,3 ; \mathrm{H}$ & $\mathbf{i}$ & + & Badel et al. 2002 \\
\hline 1373 & hrpWI & $\mathrm{D}, \mathrm{M}, \mathrm{T}$ & 1,2,3; H & $\mathbf{g}$ & + & \\
\hline
\end{tabular}

${ }^{t}$ PSPTO open reading frame (ORF) locus number. Genes are presented in the order of their PSPTO number along the DC3000 chromosome, with the four plasmid-borne effector genes (PSPTO numbers preceded with letter A) being presented last. PSPTO numbers greater than 5615 were added after the initial annotation and do not correlate with relative position in the genome.

${ }^{u}$ Genes in putative operons where an upstream ORF is disrupted by a transposable element are marked with an asterisk (*). Although the previously assigned hop names are shown for PSPTO1179, PSPTO2872, and PSPTO4996, these genes are not regulated by HrpL and are not members of any validated effector family; therefore, they do not meet the current criteria for Hops (Lindeberg et al. 2005). Bold type indicates that the Hop is likely active in DC3000. A caret $(\wedge)$ at the beginning of the row indicates that the Hop is not active in DC3000, and no special marking indicates that the functional status of the Hop is uncertain.

${ }^{v}$ Genes found to be regulated by HrpL or expressed in planta. The letters in this column indicate that the gene was found to be expressed in the following assays: D, differential fluorescence induction (DFI) (Chang et al. 2005); M, microarray or real-time polymerase chain reaction (RT-PCR) (Ferreira et al. 2006); I, in planta expression technology (IPET) (Boch et al. 2002); R, RT-PCR (Guo et al. 2005); T, miniTn5gus insertion (Fouts et al. 2002); and NE indicates that the gene was not found in any of the above studies. Note that the presence of two identical copies of hopAM1 complicates microarray analysis, and hopAN1 expression is activated by HrpL despite lacking an upstream Hrp box (Boch et al. 2002).

${ }^{w}$ Type III secretion system (T3SS) bioinformatic evidence for classification as an effector. The numbers and letters in this column represent the following characteristics: $1,>10 \%$ Ser within the first 50 amino acids; 2, an Ile, Leu, Val, or Pro at position 3 or 4 ; 3 no Asp or Glu within the first 12 codons; H, sequence similarity to other Hops; $\mathrm{C}$, interaction with T3SS chaperones.

${ }^{\mathrm{x}}$ Evidence for secretion or translocation when the protein is heterologously expressed. Experiments reporting secretion or translocation of the DC3000 protein are reported in: a, Petnicki-Ocwieja et al. 2002; b, Schechter et al. 2004; c, this work; d, Vinatzer et al. 2005; e, Zwiesler-Vollick et al. 2002; f, Shan et al. 2004; g, A. Collmer, unpublished data; h, López-Solanilla et al. 2004; i, Badel et al. 2002; j, Badel et al. 2003; k, J. R. Alfano, unpublished data; 1, van Dijk et al. 1999; m, Badel et al. 2006; n, Guo et al. 2005; o, Kabisch et al. 2005; p, Petnicki-Ocwieja et al. 2005.

${ }^{\mathrm{y}}$ Evidence for translocation when the gene is expressed from its native promoter as reported by Chang and associates $(2005)$ : + , protein is translocated; - , protein is not translocated; \pm , protein was inconsistently translocated; NT, not tested. Tests for HopS1' and HopT1-1 are from Vinatzer and associates (2005).

${ }^{\mathrm{z}}$ Mutant phenotype in planta observed. 
Schechter et al. 2004). A notable feature of the DFI study is that the follow-up translocation tests employed candidate effector genes expressed in DC3000 from their native promoter (in trans on a stable, multicopy plasmid). In addition to the 25 effectors that were reliably translocated by this approach, there were 6 proteins involving fusions with partial-length test proteins or which yielded inconsistent results, but which were cautiously scored as effectors. In essence, the DFI and native promoter translocation tests identified what appear to be the 25 most strongly expressed effector genes in DC3000. A whole-genome microarray and bioinformatic analysis of HrpL-responsive DC3000 genes also highlights this set of strongly expressed effectors (Ferreira et al. 2006). In summary, the most strongly expressed effector genes can be found through their Hrp promoters by reporter transposons (Fouts et al. 2002), DFI (Chang et al. 2005), microarray analysis (Ferreira et al. 2006), or more directly and efficiently by bioinformatic identification of such promoters in the genome sequence (Fouts et al. 2002; Guttman et al. 2002; Zwiesler-Vollick et al. 2002).

The analysis by Chang and associates (2005) also confirmed the utility of targeting-associated patterns in predicting which genes downstream of Hrp promoters encode T3SS substrates.
That is, 26 of the 31 confirmed effectors possessed all three of the primary patterns predicting T3SS substrates (Guttman et al. 2002; Petnicki-Ocwieja et al. 2002). The five exceptions were HopV1 (possessing none of the targeting-associated patterns) and HopP1, HopM1, HopAM1-1, and HopAM1-2 (all lacking the aliphatic amino acid signal pattern). However, HopAM1-1 and HopAM1-2 (which are identical proteins in DC3000) contain a hydrophobic amino acid (A) in position 3, which appears in a few other Hrp-secreted proteins (PetnickiOcwieja et al. 2002). Importantly, the five exceptions all possessed additional features that would keep them on a list of candidates worth testing in a bioinformatic analysis: the hopVl and hopMl genes are linked with obvious chaperone genes, HopP1 has a strikingly high Ser bias in its N-terminal region, and HopAM1-1 and HopAM1-2 are both homologs of the known effector AvrPpiB1. In summary, the data from Chang and associates (2005) validates the bioinformatic approach for identification of candidate effectors based on the presence of Hrp promoters and T3SS targeting-associated patterns.

It is noteworthy that targeting-associated patterns also are found in flagellar secretion substrates and in a subset of T3SS effectors in other plant and animal pathogens. For example, the

Table 3. (continued from preceding page)

\begin{tabular}{|c|c|c|c|c|c|c|}
\hline \multirow[b]{2}{*}{ Locus $^{t}$} & \multirow[b]{2}{*}{ Name $^{u}$} & \multirow[b]{2}{*}{ Expression $^{v}$} & \multirow[b]{2}{*}{ TTSS $^{w}$} & \multicolumn{2}{|c|}{ Secretion/translocation } & \multirow[b]{2}{*}{ Phenotype observed $^{\mathrm{z}}$} \\
\hline & & & & Heterologous promoter ${ }^{\mathrm{x}}$ & Native promoter ${ }^{\mathrm{y}}$ & \\
\hline 1375 & hopM1 & D, M, I & 1,3; C & $\mathbf{j}$ & + & Badel et al. 2003 \\
\hline 1377 & avrE1 & $\mathbf{D}$ & 1,2,3; H; C & $\mathbf{m}$ & \pm & Badel et al. 2006 \\
\hline 1382 & hrpZ1 & $\mathrm{D}, \mathrm{M}$ & 1,2,3; H & $\mathbf{g}$ & + & \\
\hline 1406 & hopB1 & $\mathrm{D}, \mathrm{M}$ & $1,2,3 ; H$ & $\mathbf{p}$ & + & \\
\hline 1568 & hopAF1 & $\mathrm{D}, \mathrm{M}$ & 1,2,3; H & $\mathbf{a}$ & + & \\
\hline 2678 & hopP1 & $\mathrm{D}, \mathrm{M}$ & $1,2,3$ & d & + & Collmer, unpublished \\
\hline$\wedge 1179$ & hopJ1 & - , no Hrp box & $1,2,3$ & N-terminal fragment & - & \\
\hline 1370 & hopN1 & $\mathrm{D}, \mathbf{M}, \mathbf{T}, \mathbf{I}$ & $1,2,3 ; \mathrm{C}$ & $\mathbf{h}$ & + & \\
\hline 1372 & hopAA1-1 & $\mathrm{D}, \mathrm{M}, \mathrm{T}$ & 1,2,3; H & $\mathbf{i}$ & + & Badel et al. 2002 \\
\hline 1373 & hrpW1 & $\mathbf{D}, \mathbf{M}, \mathbf{T}$ & 1,2,3; H & $\mathbf{g}$ & + & \\
\hline 1375 & hopM1 & $\mathbf{D}, \mathbf{M}, \mathbf{I}$ & 1,3; C & $\mathbf{j}$ & + & Badel et al. 2003 \\
\hline 1377 & avrE1 & D & 1,2,3; H; C & $\mathbf{m}$ & \pm & Badel et al. 2006 \\
\hline 1382 & hrpZ1 & $\mathrm{D}, \mathrm{M}$ & 1,2,3; H & $\mathbf{g}$ & + & \\
\hline 1406 & hopB1 & $\mathrm{D}, \mathrm{M}$ & $1,2,3 ; \mathrm{H}$ & p & + & \\
\hline 1568 & hopAF1 & $\mathrm{D}, \mathrm{M}$ & $1,2,3 ; \mathrm{H}$ & $\mathbf{a}$ & + & \\
\hline 2678 & hopP1 & $\mathrm{D}, \mathrm{M}$ & $1,2,3$ & d & + & Collmer, unpublished \\
\hline$\wedge 2872$ & hopL1 & - , no Hrp box & 2,3 & $\mathrm{a}$ & - & \\
\hline 3087 & avrPtoB & $\mathbf{D}, \mathbf{M}, \mathbf{T}, \mathbf{I}$ & 1,2,3; H & $\mathbf{e}$ & + & Lin and Martin 2005 \\
\hline$\wedge 3292$ & hорАН2-1 & $\mathrm{NE}$ & $1,2,3 ; \mathrm{H}$ & $\mathrm{cd}$ & NT & \\
\hline$\wedge 3293$ & hорАН2-2 & $\mathrm{NE}$ & $2 ; \mathrm{H}$ & $\mathrm{c}$ & NT & \\
\hline 4001 & avrPto1 & $\mathbf{D}, \mathbf{M}, \mathbf{T}, \mathbf{I}$ & 1,2,3; H & $\mathbf{l}$ & + & Lin and Martin 2005 \\
\hline 4101 & hopAK1 & $\mathbf{D}, \mathbf{M}, \mathbf{T}, \mathbf{I}$ & 2,3; H & $\mathbf{g}$ & - & Collmer, unpublished \\
\hline 4331 & hopE1 & $\mathrm{D}, \mathrm{M}$ & $1,2,3$ & ae & + & Alfano, unpublished \\
\hline 4588 & hopS2 & $\mathrm{D}, \mathrm{R}$ & 1,$3 ; \mathrm{H}, \mathrm{C}$ & bn & - & \\
\hline$\wedge 4590$ & hopT2* & $\mathrm{NE}$ & 1,$3 ; \mathrm{H}$ & $\mathrm{c}$ & NT & \\
\hline$\wedge 4592$ & hopO1-3'* & $\mathrm{NE}$ & $1,2,3 ; \mathrm{H}$ & $\mathrm{c}$ & NT & \\
\hline 4593 & hopT1-2* & $\mathrm{R}$ & $1 ; \mathrm{H}$ & $\operatorname{cdn}$ & - & \\
\hline 4594 & hopO1-2* & $\mathrm{R}$ & $1,2,3 ; \mathrm{H} ; \mathrm{C}$ & $\mathrm{kn}$ & \pm & \\
\hline$\wedge 4597$ & hopS1::ISPssy & $\mathrm{D}, \mathrm{M}, \mathrm{I}, \mathrm{R}$ & $1,2,3 ; \mathrm{H} ; \mathrm{C}$ & bno & + & \\
\hline 4691 & hopAD1 & $\mathrm{D}$ & $1,2,3$ & $\mathrm{a}$ & - & \\
\hline 4703 & hорAQ1 & $\mathrm{D}$ & $1,2,3$ & $\mathrm{~d}$ & - & \\
\hline 4718 & hорАА1-2 & $\mathbf{I}, \mathbf{M}$ & 1,2,3; H & g & + & Badel et al. 2002 \\
\hline 4720 & hopVI & $\mathbf{M}$ & C & b & + & \\
\hline 4722 & hорАО1 & D, M, I & 1,2,3; H & $\mathbf{a}$ & NT & Espinosa et al. 2003 \\
\hline$\wedge 4724$ & hopD::IS52 & $\mathrm{D}$ & $1,2,3 ; \mathrm{H}$ & NT & NT & $\ldots$ \\
\hline 4727 & hopG1 & $\mathrm{D}, \mathrm{M}$ & $1,2,3$ & $\mathbf{a}$ & \pm & Jamir et al. 2004 \\
\hline$\wedge 5623$ & hopH::ISPsy4 & $\mathrm{NE}$ & 2,$3 ; \mathrm{H}$ & NT & NT & $\ldots$ \\
\hline$\wedge 4732$ & hopQ1-2 & $\mathrm{M}$ & 1,$2 ; \mathrm{H}$ & NT & NT & $\ldots$ \\
\hline 4776 & hopII & $\mathbf{D}, \mathbf{M}, \mathbf{T}$ & $1,2,3 ; \mathrm{H}$ & NT & + & $\ldots$ \\
\hline$\wedge 4996$ & hopAC & $\mathrm{NE}$ & $1 ; \mathrm{H}$ & NT & NT & $\ldots$ \\
\hline 5061 & hopAN1 & $\mathrm{I}$ & $1,2,3$ & NT & NT & $\ldots$ \\
\hline 5354 & hopA1 & $\mathbf{D}, \mathbf{M}, \mathbf{T}$ & 1,2,3; H; C & NT & + & $\ldots$ \\
\hline $\mathbf{A 0 0 0 5}$ & hорАМ1-2 & $\mathbf{M}$ & 1,3; H & $\mathbf{g}$ & NT & $\ldots$ \\
\hline A0012 & hopX1 & $\mathbf{M}, \mathbf{T}$ & 1,2,3; H & b & \pm & Jamir et al. 2004 \\
\hline A0018 & hop01-1 & $\mathbf{M}$ & 1,2,3; H; C & an & + & $\ldots$ \\
\hline A0019 & hopT1-1 & $\mathbf{M}$ & $1,2,3 ; H$ & $\mathbf{b}$ & + & ... \\
\hline
\end{tabular}


Yersinia effector YopE possesses the three major patterns, including an unusually high Ser content of $28 \%$ in the first 50 residues. However, other Yersinia effectors differ. For example, YopQ has an Asp in position 5 and a Ser content of only 6\% in the first 50 residues, and YopT and YopH have an Asp within the first 7 residues. Observations such as this raised the possibility that there could be another class of effectors with quite different N-terminal amino acid patterns. However, we found no evidence for such a class despite translocation assays of the products of many candidate genes that were either downstream of Hrp promoters, linked with known effector genes, or that predicted properties that can be associated with eukaryotic functions. Thus, our analysis suggests that searching $P$. syringae genomes for open reading frames (ORFs) that are downstream of Hrp promoters and that possess the targeting-associated amino acid patterns (or are linked to candidate chaperone genes) will yield virtually all of the effectors in that strain. Although these patterns have confirmed predictive value in $P$. syringae, it is important to note that their function remains to be tested.

The analysis of Chang and associates (2005) also revealed 10 candidates that did not deliver $\Delta 79$ AvrRpt 2 into plant cells despite possession of all of the targeting-associated patterns. This raises the concern that analysis of HrpL-regulated genes for targeting-associated patterns yields false positives. There are several reasons why we think that this is not the case. At least five of these predicted proteins are candidate helpers (proteins such as harpins that travel the T3SS but, unlike true effectors, are targeted to the apoplast rather than the host cytoplasm) (Collmer et al. 2002). These proteins would be expected to inefficiently deliver $\Delta 79 \mathrm{AvrRpt} 2$ to plant cells. Of the remaining four proteins, HopAQ1 is otherwise untested, but HopS2, HopAD1, and HopT1-1 had been reported previously to be secreted or translocated by the T3SS when constitutively expressed from vector promoters (Petnicki-Ocwieja et al. 2002; Schechter et al. 2004). We consider these to be true effectors, although we cannot say that they are active in DC3000 pathogenesis.

Several potential limitations in the AvrRpt 2 delivery test are worth noting. Some effectors may suppress HR development and, thereby, interfere with the assay (Abramovitch et al. 2003; Jackson et al. 1999; Jamir et al. 2004). For example, HopX1 and HopG1 are suppressors of cell death that have mutant phenotypes (enhanced HR in nonhost tobacco) but were rated as producing only "inconsistent translocation results" by Chang and associates (2005). It also is possible that some effectors may specifically block AvrRpt 2 action by protecting RIN4 (Axtell and Staskawicz 2003; Mackey et al. 2003). A more general problem is sensitivity. AvrRpt 2 has been reported to produce a weaker HR than other effectors, such as AvrRpm1 and AvrB (Leister et al. 1996; Reuber and Ausubel 1996; Ritter and Dangl 1996). More importantly, we presently have no idea what levels are needed for the virulence functions of any effector.

We can expect the dynamics of effector genetics in $P$. syringae to involve not only the obvious events of horizontal acquisition, deletion, and disruption by mobile genetic elements but also more subtle changes affecting transcription, translation, stability, and effector delivery. Furthermore, as discussed below, loss of effector function actually may contribute to virulence. Therefore, we think that it is important to identify all effectors (whether active or not) in reference strains such as DC3000 and to analyze separately each stage in the deployment of these effectors. Quantitative Cya translocation reporter assays employing effectors expressed from a reference promoter such as the tac promoter are an important part of this analysis, and these standardized translocation assays usefully complement microarray and real-time PCR analyses of the relative expression of the respective effector genes.

\section{Analysis of nonfunctional effectors.}

Effectors can betray $P$. syringae strains to the $R$ gene surveillance system, and they can interfere with each other's action. Furthermore, it is likely that $P$. syringae strains can readily acquire new effectors because many effector genes are associated with mobile genetic elements, recombination hot spots, and other factors associated with horizontal acquisition (Alfano et al. 2000; Arnold et al. 2001; Kim et al. 1998; Rohmer et al. 2003). Thus, it is possible that selection pressure for the inactivation of an effector may result from the acquisition of new gene functions in both the host and the bacterium and that loss of effector function may be an important factor in the evolution of $P$. syringae virulence. Loss of gene function has been a contributing factor to the evolution of virulence of many pathogens (Ochman and Moran 2001), and the existence of disrupted effector genes has been observed before. For example, analyses of the hopXl (avrPphE) alleles in P. syringae pv. phaseolicola and of the exchangeable effector loci in multiple $P$. syringae pathovars have provided snapshots of the disruption of a few effectors in multiple strains and pathovars (Deng et al. 2003; Stevens et al. 1998).

Here, we document the lack of function for multiple effector genes in a single strain. We have shown that several DC3000 effectors are unlikely to be active for various reasons: i) the hopAG and hopS1 ORFs were disrupted by transposable elements; ii) hopAI1, hopAH1, hopO1-3', hopT1-2, hopAS1', hopAH2-1, hopAH2-2, and PSPTO0907 do not appear to be expressed during infection; and iii) HopT2, HopQ1-2, and HopAC1 are not translocated even when constitutively expressed. To test the possibility that the apparent inactivity of these effectors was beneficial to DC3000, we restored several to function, as confirmed by translocation of appropriate HopCya hybrids into $N$. benthamiana cells. However, none of these newly activated effectors had any observable effect on the ability of DC3000 to grow or produce symptoms in Arabidopsis Col-0 or tomato cv. Moneymaker. It is possible that the C-terminal Cya fusion interfered with the function of one or more of these test Hops. However, we have not observed the presence of Cya to disrupt the functions of several other effectors (Badel et al. 2006; Schechter et al. 2004). It also is possible that an effect would be seen if we tested a wider range of host plants among tomato cultivars and related species or among different members of the Brassicaceae. In addition, these effector genes may simply be relics of previous horizontal acquisition events (possibly involving multiple effectors) and these particular effector genes may have no relevance to DC3000 virulence. Nevertheless, it is important to note that a significant portion of the DC3000 effector inventory may not be active. Interestingly, all of the hop genes encoded in the conserved effector locus and on plasmid pDC3000A appear to be active. Thus, the effectors that are likely to be most important in DC3000 include those that are most conserved in all $P$. syringae strains (Alfano et al. 2000), as well as those that are likely to be highly mobile.

\section{Analysis of the complete inventory}

of type III effector genes in P. syringae pv. tomato DC3000.

For purposes of guiding future research, effectors can be divided into three categories. First are those that are demonstrably active based on a mutant phenotype or likely active because of native promoter translocation tests or because of microarray and Cya-translocation data indicating strong HrpL-dependent expression and translocation (Chang et al. 2005; Ferreira et al. 2006; Schechter et al. 2004). These are high-priority targets for 
research on effector function in pathogenesis. Second are effector genes that are members of validated effectors families but are unlikely to be active in DC3000 because of lack of expression, insertion or frameshift mutations, or inability to be translocated. These inactive genes are of interest for evolutionary studies. The third category includes Hop proteins that are produced more weakly or which may function primarily in the apoplast. These invite further study of deployment and function to establish their status. We generally have little insight into the significance of the greatly varying levels of expression or translocation of various Hops. Nevertheless, our data suggest that the inventory of hop genes (including those encoding both true effectors and helpers, but excluding HrpA, HrpK, and other extracellular components of the T3SS machinery) is nearly complete at 53. As summarized in Table 3, 33 of these are likely to be active effectors or apoplast-targeted Hops, 12 are likely to be inactive, and 8 may or may not be produced at functional levels. Almost all of these hop genes are associated in the DC3000 genome with Hrp promoters (albeit separated by mobile genetic elements in some cases or associated with Hrp promoters only in other strains in other cases), which facilitates their identification by bioinformatic means. The challenge now is to learn why DC3000 has such a complex inventory of effector genes.

\section{MATERIALS AND METHODS}

\section{Bacterial strains and growth conditions.}

The $P$. syringae strains used in this study are listed in Table 4 and were grown in King's B medium (KB) at $30^{\circ} \mathrm{C}$ (King et al. 1954) or hrp-derepressing fructose minimal media (Huynh et al. 1989) at $22^{\circ} \mathrm{C}$. Escherichia coli strains used for cloning and propagating plasmids were grown in Luria-Bertani or Terrific Broth at $37^{\circ} \mathrm{C}$ (Miller 1992). Antibiotics were used at the following concentrations: chloramphenicol, $20 \mu \mathrm{g} / \mathrm{ml}$; cycloheximide, $2 \mu \mathrm{g} / \mathrm{ml}$; kanamycin, $50 \mu \mathrm{g} / \mathrm{ml}$; rifampin, $50 \mu \mathrm{g} / \mathrm{ml}$; and spectinomycin, $50 \mu \mathrm{g} / \mathrm{ml}$.

\section{DNA manipulations.}

Plasmid DNA was isolated and manipulated according to standard protocols (Sambrook et al. 1989). PCR was performed with either ExTaq (Takara; Otsu, Shiga, Japan) or Vent (New England Biolabs, Ipswich, MA, U.S.A.). DNA sequencing was performed by the Cornell BioResource Center with a 3700 DNA analyzer (Applied Biosystems; Foster City, CA, U.S.A.).

\section{Construction of plasmids and bacterial mutants.}

Plasmids expressing Cya fusion proteins were constructed by Gateway cloning technology (Invitrogen). Candidate effector genes were amplified from DC3000 chromosomal DNA by PCR using the relevant primers listed in Table 5, and the products were cloned into the Gateway entry vector $\mathrm{pENTR/SD/D-}$ TOPO (Invitrogen). The candidate effector genes contained in these plasmids were sequenced to confirm that no mutations were present. Recombination (or LR) reactions between each entry vector and the destination vector pCPP3234 (Schechter et al. 2004) then were performed to create the pVLT35-based expression plasmids described in Table 4. These plasmids were maintained in E. coli TOP10 (Invitrogen). The transposable elements in hopAG and hopS1 were removed by crossover PCR as described previously (Link et al. 1997) before these genes were cloned into $\mathrm{pENTR/SD/D-TOPO.}$

$P$. syringae strains containing chromosomal IPET fusions to effector gene promoters were constructed using previously described methods (Boch et al. 2002). The relevant promoter regions were amplified by PCR using the primers listed in Table 5 and ligated to pIPET digested with KpnI and XhoI. Because pIPET has an R6K origin of replication that depends on the $\pi$ protein, these plasmids were maintained in DH5 $\alpha(\lambda$ pir $)$. Next, the pIPET derivatives were conjugated into $P$. syringae TLR1, and strains containing integrated pIPET plasmids were selected by plating on KB-rifampin-spectinomycin-kanamycin medium. Correct integration of the plas-

Table 4. Pseudomonas syringae strains and plasmids used in this study

\begin{tabular}{|c|c|c|}
\hline Strain or plasmid & Genotype or relevant phenotype $^{z}$ & Source \\
\hline \multicolumn{3}{|c|}{ P. syringae pv. tomato strains } \\
\hline DC3000 & Wild type, Rif $^{\mathrm{T}}$ & Cuppels 1986 \\
\hline CUCPB5114 & DC3000 $\Delta h r p K-h r p R:: \Omega C m, \operatorname{Rif}^{\mathrm{r}} \mathrm{Cm}^{\mathrm{r}}$ & Fouts et al. 2003 \\
\hline UNL134-1 & DC3000 $\Delta h r p L:: \Omega S p, \operatorname{Rif}^{\mathrm{T}} \mathrm{Sp}^{\mathrm{r}}$ & Ferreira et al. 2006 \\
\hline TLR1 & $\mathrm{DC} 3000 \Delta h r c C:: \Omega S p, \mathrm{Rif}^{\mathrm{T}} \mathrm{Sp}^{\mathrm{r}}$ & Boch et al. 2002 \\
\hline JB200 & TLR1 $a v r P t o^{\text {for }}::$ pIPET, $\operatorname{Rif}^{\mathrm{T}} \mathrm{Sp}^{\mathrm{r}} \mathrm{Kan}^{\mathrm{r}}$ & Boch et al. 2002 \\
\hline JB201 & TLR1 avrPto ${ }^{\text {rev }}:$ :pIPET, Rif $^{r} \mathrm{Sp}^{\mathrm{r}} \mathrm{Kan}^{\mathrm{r}}$ & Boch et al. 2002 \\
\hline CUCPB5430 & TLR1 hopAS1'::pIPET, $\operatorname{Rif}^{\mathrm{T}} \mathrm{Sp}^{\mathrm{r}} \mathrm{Kan}^{\mathrm{r}}$ & This work \\
\hline CUCPB5431 & TLR1 hopR1::pIPET, $\operatorname{Rif}^{\mathrm{r}} \mathrm{Sp}^{\mathrm{r}} \mathrm{Kan}^{\mathrm{r}}$ & This work \\
\hline CUCPB5432 & TLR1 hopAH2-1::pIPET, $\operatorname{Rif}^{\mathrm{r}} \mathrm{Sp}^{\mathrm{r}} \mathrm{Kan}^{\mathrm{r}}$ & This work \\
\hline CUCPB5433 & TLR1 hopAH2-2::pIPET, $\operatorname{Rif}^{\mathrm{r}} \mathrm{Sp}^{\mathrm{r}} \mathrm{Kan}^{\mathrm{r}}$ & This work \\
\hline \multicolumn{3}{|c|}{ 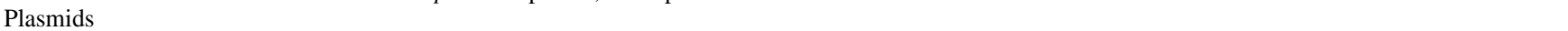 } \\
\hline pCPP3234 & pVLT35 containing Gateway reading frame B cassette and codons 2 to 406 of $c y a, \mathrm{Sp}^{\mathrm{r}} / \mathrm{Str}^{\mathrm{r}} \mathrm{Cm}^{\mathrm{r}}$ & Schechter et al. 2004 \\
\hline pCPP3450 & pCPP3234 expressing HopY1-Cya & This work \\
\hline pCPP3458 & pCPP3234 expressing HopR1(201)-Cya & This work \\
\hline pCPP3470 & pCPP3234 expressing HopAH2-1-Cya & This work \\
\hline pCРP3471 & pCРP3234 expressing НорАН2-2-Суа & This work \\
\hline рСРР3476 & pCРP3234 expressing НорВ2(400)-Суа & This work \\
\hline pCРP3491 & pCPP3234 expressing HopAG'-Cya & This work \\
\hline рСРР3492 & pCPP3234 expressing HopS1'-Cya & This work \\
\hline pCPP5147 & pCPP3234 expressing HopAS1'-Cya & This work \\
\hline pCPP5119 & pCPР3234 expressing НорАН1-Сya & This work \\
\hline pCPP5120 & pCPP3234 expressing PSPTO0907-Сya & This work \\
\hline pCPP5121 & pCPP3234 expressing HopQ2-Сya & This work \\
\hline pCPP5129 & pCPP3234 expressing HopAI1-Cya & This work \\
\hline pCPP5130 & pCРP3234 expressing НорТ2-Сya & This work \\
\hline pCРP5131 & pCPP3234 expressing HopO1-3'-Cya & This work \\
\hline pCPP5133 & pCPP3234 expressing HopT1-2-Сya & This work \\
\hline pIPET & Suicide plasmid carrying a promoterless copy of $h r c C, \operatorname{Kan}^{\mathrm{r}}$ & Boch et al. 2002 \\
\hline
\end{tabular}

${ }^{\mathrm{z}}$ Cya $=$ Bordetella pertussis adenylate cyclase. $\mathrm{Rif}^{\mathrm{r}}, \mathrm{Cm}^{\mathrm{r}}, \mathrm{Sp}^{\mathrm{r}}, \mathrm{Kan}^{\mathrm{r}}$, and $\mathrm{Str}^{\mathrm{r}}=$ rifampin-, chloramphenicol-, spectinomycin-, kanamycin-, and streptomycinresistant, respectively. 
mids was confirmed by two PCR reactions using primers that flanked each end of the insertion site.

\section{Adenylate cyclase assays.}

cAMP levels in infected $N$. benthamiana leaf tissue were determined as described previously (Schechter et al. 2004). Briefly, $P$. syringae strains were suspended to an optical density at $600 \mathrm{~nm}$ of $0.3\left(1 \times 10^{8} \mathrm{CFU} / \mathrm{ml}\right)$ in a solution containing $5 \mathrm{mM}$ morpholinoethanesulfonic acid (pH 6.0) and 100 $\mu \mathrm{M}$ IPTG. Bacteria were infiltrated into plant tissue with a blunt syringe, and samples were collected $7 \mathrm{~h}$ post inoculation with a $0.8-\mathrm{cm}$-diameter cork borer. Leaf disks then were frozen in nitrogen, ground to a powder, and suspended in $300 \mu \mathrm{l}$ of $0.1 \mathrm{M} \mathrm{HCl}$. cAMP was quantified using the Correlate-EIA cAMP immunoassay kit (Assay Designs, Ann Arbor, MI, U.S.A.) and protein levels were determined by the Bio-Rad protein assay (Bio-Rad, Richmond, CA, U.S.A.) according to the manufacturer's directions. As noted previously (Schechter et al. 2004), some batches of plants can yield higher or lower levels of cAMP in Cya translocation assays for all test strains. Therefore, it is important to include reference strains in each experiment for quantitative comparisons.

\section{Real-time PCR.}

Real-time PCR was performed in an ABI 7000 Sequence Detection System (Applied Biosystems) and is described in detail elsewhere (Vencato et al. 2006). Briefly, PCR reactions contained iTaq Sybr Green Supermix with Rox (Bio-Rad), $P$. syringae cDNA, and $0.3 \mu \mathrm{M}$ of the relevant primers listed in Table 5. The cDNA in the PCR reactions was reverse tran- scribed from total RNA using the cDNA synthesis kit (BioRad). Total RNA was extracted from $P$. syringae using the SV Total RNA Isolation System (Promega Corp., Madison, WI, U.S.A.) and the RNeasy Minikit (Qiagen, Hilden, Germany) (Vencato et al. 2006). The efficacy of all primer pairs was confirmed using DC3000 DNA templates. The threshold cycle $(\mathrm{Ct})$ value of each gene tested was normalized to the $\mathrm{Ct}$ values of two housekeeping genes, gyrA (PSPTO1745) and gapl (PSPTO1287), separately, and these values then were averaged to obtain relative expression data for each gene in wild-type DC3000 and hrpL mutant strains.

\section{Virulence and HR assays.}

$P$. syringae growth in planta was determined as previously described (López-Solanilla et al. 2004). Briefly, tomato plants (Solanum lycopersicum cv. Money Maker) were grown under greenhouse conditions for 3 to 4 weeks and dipped for $30 \mathrm{~s}$ in a $10 \mathrm{mM} \mathrm{MgCl}_{2}, 0.02 \%$ Silwet solution containing the test strains at $5 \times 10^{6} \mathrm{CFU} \mathrm{ml}{ }^{-1}$. Infected plants were maintained in a growth chamber at $25^{\circ} \mathrm{C}$ with illumination $(16 \mathrm{~h}$ of light and $8 \mathrm{~h}$ of dark) during the course of the experiment. At various time points, 10 leaf samples were collected with a $0.7-\mathrm{cm}$ boring tool and weighed. The leaf tissue then was homogenized in $0.5 \mathrm{ml}$ of $10 \mathrm{mM} \mathrm{MgCl}$ and bacterial counts were determined by plating a series of dilutions on KB-rifampin-cycloheximide medium.

For HR assays, N. tabacum cv. Xanthi plants were grown under greenhouse conditions for 4 to 6 weeks. Bacteria were infiltrated into leaf tissue using a blunt syringe, and plants were maintained in the laboratory with illumination at room temperature $\left(24^{\circ} \mathrm{C}\right)$.

Table 5. Primers used in this study

\begin{tabular}{|c|c|c|}
\hline Gene & $5^{\prime}$ (upstream) primer & $3^{\prime}$ (downstream) primer \\
\hline \multicolumn{3}{|l|}{ For construction of cya fusions ${ }^{\mathrm{z}}$} \\
\hline hopY1 (PSPTO0061) & 5'-CACCATGAACATTACGCCGCTCACG-3' & 5'-CTGGTAGTTGATGCCCGTGG-3' \\
\hline hopAS1' (PSPTO0474) & 5'-CACCATGACCTTAAGAATCAATAC- $3^{\prime}$ & 5'-AGAAAACTCGGCTTTCTGTT-3' \\
\hline hopRl (PSPTO0883) & 5'-CACCATGGTCAAGGTTACCTCTTCC-3' & 5'-GGGATTGATGCCTGGCAGCG-3' \\
\hline hopAH1 (PSPT O0905) & 5'-CACCATGAGTATGAATACCTCTGTAAGC-3' & 5'-GGAGAATTGATCCCCTTTCG-3' \\
\hline hopAIl (РSPTO0906) & 5'-CACCATGCTCGCTTTGAAGCTGAA-3' & 5'-GCGAGTCCAGGGCGGTGGCA-3' \\
\hline PSPTO0907 & 5'-CACCATGCCACATCCAGTCTCTCA-3' & 5'-GCGTTCGCCATAAGCAAGCC-3' \\
\hline hорАH2-1 (PSPTO3292) & 5'-CACCATGAATATCAATTCAATCCGGTC-3' & 5'-GTATTGATCTGACTTTGAAAATCCGAC-3' \\
\hline hopAH2-2 (PSPTO3293) & 5'-CACCATGAACATCCACACCGCC-3' & 5'-TGAGTACTGATCTGACTTTGAAAATCCG-3' \\
\hline hopO1-3' (PSPTO4592) & 5'-CACCATGAATATTAACCCTTC-3' & 5'-GTGTTGATACCGAAGATGAT-3' \\
\hline hopT1-2 (PSPTO4593) & 5'-CACCATGATCAAAACAGTCAGCCGA-3' & 5'-GCCTACCCGATCAGCGGCTG-3' \\
\hline hopAC (PSPTO4996) & 5'-CACCATGTGGGGTTCGTGGATC-3' & 5'-CGAGCTGAACGGTCGCACCT-3' \\
\hline hopT2 (PSPTO4590) & 5'-CACCGTGTTTTGCCGCC-3' & 5'-CCATGACGCTTTATTGGCTG-3' \\
\hline hopQ1-2 (PSPTO4732) & 5'-CACCATGAGCAGCCCAGCTTTGGA-3' & 5'-ATCCGGGACTGCCGTCGACT-3' \\
\hline hopAG $(\mathrm{PSPTO} 0901)$ & 5'-CACCATGAACCCTATAACACACAGCTTTAG-3' & $\begin{array}{l}\text { 5'-CGGTATAAACACCTTTAACTACCCGCAAGCC- } \\
\text { ATGG-3' }\end{array}$ \\
\hline 'hopAG (PSPTO0904) & $\begin{array}{l}\text { 5'-CCATGGCTTGCGGGTAGTTAAAGGTGTTTAT- } \\
\text { ACCG-3' }\end{array}$ & 5'-GAAGGGGTTAAGCCTGAAAACC-3' \\
\hline hopS1' (PSPTO4597) & 5'-CACCATGAATGCGTTCGCAACCG-3' & $\begin{array}{l}\text { 5'-CGTCGTCATCAAGGTGACCAAGCTCTGGA- } \\
\text { TTTTTATC-3' }\end{array}$ \\
\hline 'hopS1 (PSPTO4595) & $\begin{array}{l}\text { 5'-GATAAAAATCCAGAGCTTGGTCACCTTGA- } \\
\text { TGACGACG-3' }\end{array}$ & 5'-TATGCCACCTTCCCGAGTCTG-3' \\
\hline \multicolumn{3}{|c|}{ 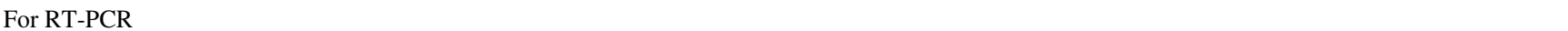 } \\
\hline hopAS1' (PSPTO0474) & 5'-TCCGAACGTCAGACCAATTTC-3' & 5'-TCGATACCTGCTCACCTTCCTC-3' \\
\hline hopR1 (PSPTO0883) & 5'-GCAAATACAAGTGCAGCTGGG-3' & 5'-TCTGGTTCAGGTTTTACGCGG-3' \\
\hline hорAH1 (PSPTO0905) & 5'-TTGATCAAGTCTGCGCGTGA-3' & 5'-CGTATTTGACCAGTCCGCTTTC-3' \\
\hline PSPTO0907 & 5'-CCACATCGAAACACAGTTGGC-3' & 5'-CCTGTCGCACCTTTCAACAGA-3' \\
\hline hорAH2-1 (PSPTO3292) & 5'-GGTCAAAAAATTCGGCGGTC-3' & 5'-TCAGCGTACTTTCCATGTCAGC-3' \\
\hline hорAH2-2 (PSPTO3293) & 5'-CCACCAAGATGATTCAGGACCT-3' & 5'-AGCTTGTCCATCTGCTTGACGT-3' \\
\hline hopO1-3' (PSPTO4592) & 5'-CTGTTTTTCGCCGTGCCTT-3' & 5'-CCCCTGAATGTTGCTGGAGTAA-3' \\
\hline hopT1-2 (PSPTO4593) & 5'-CGGATGGAAATCTGTACGCA-3' & 5'-CCGAGGTTTGAAGCAGACTCAA-3' \\
\hline \multicolumn{3}{|c|}{ For cloning promoters into pIPET } \\
\hline hopAS1' (PSPTO0474) & 5'-CCGGTACCATCTTTCTTGCAACCTTCATCAC-3' & 5'-GGCTCGAGCGGGCTCCATCGGCT-3' \\
\hline hopR1 (PSPTO0883) & 5'-GAGGTACCGTGGAGGTTGATAGGCA-3' & 5'-GGCTCGAGATCGTTATTATTAAACTCCTG-3' \\
\hline hорАH2-1 (PSPTO3292) & 5'-GAGGTACCGTGACCCGATTGGCAGTG-3' & 5'-GCCTCGAGAGCGTCTCTTTCTGAGC-3' \\
\hline hopAH2-2 (PSPTO3293) & 5'-GCGGTACCAGGACACCAAGGAGATG-3' & 5'-GGCTCGAGAATGTCTCTGTGGGCTCTG-3' \\
\hline
\end{tabular}

${ }^{\mathrm{z}} \mathrm{Cya}=$ Bordetella pertussis adenylate cyclase $;$ RT-PCR $=$ real-time polymerase chain reaction; pIPET $=$ in planta expression technology. 


\section{ACKNOWLEDGMENTS}

This work was supported by National Science Foundation Plant Genome Research Program Cooperative Agreement DBI-0077622. We thank B. Kunkel for providing pIPET and DC3000 derivatives TLR1, JB200, and JB201 and J. Alfano for providing UNL134-1.

\section{LITERATURE CITED}

Abramovitch, R. B., Kim, Y. J., Chen, S., Dickman, M. B., and Martin, G. B. 2003. Pseudomonas type III effector AvrPtoB induces plant disease susceptibility by inhibition of host programmed cell death. EMBO (Eur. Mol. Biol. Organ.) J. 22:60-69.

Alfano, J. R., Charkowski, A. O., Deng, W.-L., Badel, J. L., PetnickiOcwieja, T., van Dijk, K., and Collmer, A. 2000. The Pseudomonas syringae Hrp pathogenicity island has a tripartite mosaic structure composed of a cluster of type III secretion genes bounded by exchangeable effector and conserved effector loci that contribute to parasitic fitness and pathogenicity in plants. Proc. Natl. Acad. Sci. U.S.A. 97:48564861 .

Arnold, D. L., Jackson, R. W., Fillingham, A. J., Goss, S. C., Taylor, J. D., Mansfield, J. W., and Vivian, A. 2001. Highly conserved sequences flank avirulence genes: isolation of novel avirulence genes from Pseudomonas syringae pv. pisi. Microbiology 147:1171-1182.

Axtell, M. J., and Staskawicz, B. J. 2003. Initiation of RPS2-specified disease resistance in Arabidopsis Is coupled to the AvrRpt2-directed elimination of RIN4. Cell 112:369-377.

Badel, J. L., Charkowski, A. O., Deng, W.-L., and Collmer, A. 2002. A gene in the Pseudomonas syringae pv. tomato Hrp pathogenicity island conserved effector locus, hopPtoAl, contributes to efficient formation of bacterial colonies in planta and is duplicated elsewhere in the genome. Mol. Plant-Microbe Interact. 15:1014-1024.

Badel, J. L., Nomura, K., Bandyopadhyay, S., Shimizu, R., Collmer, A., and He, S. Y. 2003. Pseudomonas syringae pv. tomato DC3000 HopPtoM (CEL ORF3) is important for lesion formation but not growth in tomato and is secreted and translocated by the Hrp type III secretion system in a chaperone-dependent manner. Mol. Microbiol. 49:12391251.

Badel, J. L., Shimizu, R., Oh, H.-S., and Collmer, A. 2006. A Pseudomonas syringae pv. tomato avrE1/hopM1 mutant is severely reduced in growth and lesion formation in tomato. Mol. Plant-Microbe Interact. 19:99-111

Boch, J., Joardar, V., Gao, L., Robertson, T. L., Lim, M., and Kunkel, B. N. 2002. Identification of Pseudomonas syringae genes induced during infection of Arabidopsis thaliana. Mol. Microbiol. 44:73-88.

Buell, C. R., Joardar, V., Lindeberg, M., Selengut, J., Paulsen, I. T., Gwinn, M. L., Dodson, R. J., Deboy, R. T., Durkin, A. S., Kolonay, J. F., Madupu, R., Daugherty, S., Brinkac, L., Beanan, M. J., Haft, D. H., Nelson, W. C., Davidsen, T., Liu, J., Yuan, Q., Khouri, H., Fedorova, N., Tran, B., Russell, D., Berry, K., Utterback, T., Vanaken, S. E., Feldblyum, T. V., D’Ascenzo, M., Deng, W.-L., Ramos, A. R., Alfano, J. R., Cartinhour, S., Chatterjee, A. K., Delaney, T. P., Lazarowitz, S. G., Martin, G. B., Schneider, D. J., Tang, X., Bender, C. L., White, O., Fraser, C. M., and Collmer, A. 2003. The complete sequence of the Arabidopsis and tomato pathogen Pseudomonas syringae pv. tomato DC3000. Proc. Natl. Acad. Sci. U.S.A. 100:10181-10186.

Casper-Lindley, C., Dahlbeck, D., Clark, E. T., and Staskawicz, B. J. 2002. Direct biochemical evidence for type III secretion-dependent translocation of the AvrBs2 effector protein into plant cells. Proc. Natl. Acad. Sci. U.S.A. 99:8336-8341.

Chang, J. H., Urbach, J. M., Law, T. F., Arnold, L. W., Hu, A., Gombar, S., Grant, S. R., Ausubel, F. M., and Dangl, J. L. 2005. A high-throughput, near-saturating screen for type III effector genes from Pseudomonas syringae. Proc. Natl. Acad. Sci. U.S.A. 102:2549-2554.

Collmer, A., Lindeberg, M., Petnicki-Ocwieja, T., Schneider, D. J., and Alfano, J. R. 2002. Genomic mining type III secretion system effectors in Pseudomonas syringae yields new picks for all TTSS prospectors. Trends Microbiol. 10:462-469.

Cuppels, D. A. 1986. Generation and characterization of Tn5 insertion mutations in Pseudomonas syringae pv. tomato. Appl. Environ. Microbiol. 51:323-327.

Deng, W., Puente, J. L., Gruenheid, S., Li, Y., Vallance, B. A., Vazquez, A., Barba, J., Ibarra, J. A., O’Donnell, P., Metalnikov, P., Ashman, K., Lee, S., Goode, D., Pawson, T., and Finlay, B. B. 2004. Dissecting virulence: systematic and functional analyses of a pathogenicity island. Proc. Natl. Acad. Sci. U.S.A. 101:3597-3602.

Deng, W.-L., Rehm, A., Charkowski, A., Rojas, C. M., and Collmer, A. 2003. Pseudomonas syringae exchangeable effector loci: sequence diversity in representative pathovars and virulence function in $P$. syringae pv. syringae B728a. J. Bacteriol. 185:2592-2602.

Espinosa, A., Guo, M., Tam, V. C., Fu, Z. Q., and Alfano, J. R. 2003. The Pseudomonas syringae type III-secreted protein HopPtoD2 possesses protein tyrosine phosphatase activity and suppresses programmed cell death in plants. Mol. Microbiol. 49:377-387.

Ferreira, A. O., Myers, C. R., Gordon, J. S., Martin, G. B., Vencato, M., Collmer, A., Wehling, M. D., Alfano, J. R., Moreno-Hagelsieb, G., Lamboy, W. F., DeClerck, G., Schneider, D. J., and Cartinhour, S. W. 2006. Whole-genome expression profiling defines the HrpL regulon of Pseudomonas syringae pv. tomato DC3000, allows de novo reconstruction of the Hrp cis element, and identifies novel co-regulated gene. Mol. Plant-Microbe Interact. 19:1167-1179.

Fouts, D. E., Abramovitch, R. B., Alfano, J. R., Baldo, A. M., Buell, C. R., Cartinhour, S., Chatterjee, A. K., D’Ascenzo, M., Gwinn, M. L., Lazarowitz, S. G., Lin, N.-C., Martin, G. B., Rehm, A. H., Schneider, D. J., van Dijk, K., Tang, X., and Collmer, A. 2002. Genomewide identification of Pseudomonas syringae pv. tomato DC3000 promoters controlled by the HrpL alternative sigma factor. Proc. Natl. Acad. Sci. U.S.A. 99:2275-2280.

Fouts, D. E., Badel, J. L., Ramos, A. R., Rapp, R. A., and Collmer, A. 2003. A Pseudomonas syringae pv. tomato DC3000 Hrp (type III secretion) deletion mutant expressing the Hrp system of bean pathogen $P$. syringae pv. syringae 61 retains normal host specificity for tomato. Mol. Plant-Microbe Interact. 16:43-52.

Greenberg, J. T., and Vinatzer, B. A. 2003. Identifying type III effectors of plant pathogens and analyzing their interaction with plant cells. Curr. Opin. Microbiol. 6:20-28.

Guo, M., Chancey, S. T., Tian, F., Ge, Z., Jamir, Y., and Alfano, J. R. 2005. Pseudomonas syringae type III chaperones ShcO1, ShcS1, and ShcS2 facilitate translocation of their cognate effectors and can substitute for each other in the secretion of HopO1-1. J. Bacteriol. 187:4257-4269.

Guttman, D. S., Vinatzer, B. A., Sarkar, S. F., Ranall, M. V., Kettler, G., and Greenberg, J. T. 2002. A functional screen for the Type III (Hrp) secretome of the plant pathogen Pseudomonas syringae. Science 295:1722-1726.

Huynh, T. V., Dahlbeck, D., and Staskawicz, B. J. 1989. Bacterial blight of soybean: Regulation of a pathogen gene determining host cultivar specificity. Science 245:1374-1377.

Jackson, R. W., Athanassopoulos, E., Tsiamis, G., Mansfield, J. W., Sesma, A., Arnold, D. L., Gibbon, M. J., Murillo, J., Taylor, J. D., and Vivian, A. 1999. Identification of a pathogenicity island, which contains genes for virulence and avirulence, on a large native plasmid in the bean pathogen Pseudomonas syringae pathovar phaseolicola. Proc. Natl. Acad. Sci. U.S.A. 96:10875-10880.

Jamir, Y., Guo, M., Oh, H.-S., Petnicki-Ocwieja, T., Chen, S., Tang, X., Dickman, M. B., Collmer, A., and Alfano, J. R. 2004. Identification of Pseudomonas syringae type III secreted effectors that suppress programmed cell death in plants and yeast. Plant J. 37:554-565.

Kabisch, U., Landgraf, A., Krause, J., Bonas, U., and Boch, J. 2005. Type III secretion chaperones ShcS1 and ShcO1 from Pseudomonas syringae pv. tomato DC3000 bind more than one effector. Microbiology 151:269-80.

Kim, J. F., Charkowski, A. O., Alfano, J. R., Collmer, A., and Beer, S. V. 1998. Sequences related to transposable elements and bacteriophages flank avirulence genes of Pseudomonas syringae. Mol. Plant-Microbe Interact. 11:1247-1252.

King, E. O., Ward, M. K., and Raney, D. E. 1954. Two simple media for the demonstration of pyocyanin and fluorescin. J. Lab. Clin. Med. 44:301-307.

Leister, R. T., Ausubel, F. M., and Katagiri, F. 1996. Molecular recognition of pathogen attack occurs inside of plant cells in plant disease resistance specified by the Arabidopsis genes RPS 2 and RPM1. Proc. Natl. Acad. Sci. U.S.A. 93:15497-15502.

Lin, N. C., and Martin, G. B. 2005. An avrPto/avrPtoB mutant of Pseudomonas syringae pv. tomato DC3000 does not elicit Pto-specific resistance and is less virulent on tomato. Mol. Plant-Microbe Interact. 18:43-51.

Lindeberg, M., Stavrinides, J., Chang, J. H., Alfano, J. R., Collmer, A., Dangl, J. L., Greenberg, J. T., Mansfield, J. W., and Guttman, D. S. 2005. Proposed guidelines for a unified nomenclature and phylogenetic analysis of type III Hop effector proteins in the plant pathogen Pseudomonas syringae. Mol. Plant-Microbe Interact. 18:275-282.

Link, A. J., Phillips, D., and Church, G. M. 1997. Methods for generating precise deletions and insertions in the genome of wild-type Escherichia coli: application to open reading frame characterization. J. Bacteriol. 179:6228-6237.

López-Solanilla, E., Bronstein, P. A., Schneider, A. R., and Collmer, A. 2004. HopPtoN is a Pseudomonas syringae Hrp (type III secretion system) cysteine protease effector that suppresses pathogen-induced necrosis associated with both compatible and incompatible plant interactions. Mol. Microbiol. 54:353-365. 
Mackey, D., Belkhadir, Y., Alonso, J. M., Ecker, J. R., and Dangl, J. L. 2003. Arabidopsis RIN4 Is a target of the type III virulence effector AvrRpt2 and modulates RPS2-mediated resistance. Cell 112:379-389.

Miao, E. A., and Miller, S. I. 2000. A conserved amino acid sequence directing intracellular type III secretion by Salmonella typhimurium. Proc. Natl. Acad. Sci. U.S.A. 97:7539-7544.

Miller, J. H. 1992. A Short Course in Bacterial Genetics: A Laboratory Manual and Handbook for Escherichia coli and related bacteria. Cold Spring Harbor Laboratory Press, Cold Spring Harbor, NY, U.S.A..

Ochman, H., and Moran, N. A. 2001. Genes lost and genes found: evolution of bacterial pathogenesis and symbiosis. Science 292:1096-1099.

Panina, E. M., Mattoo, S., Griffith, N., Kozak, N. A., Yuk, M. H., and Miller, J. F. 2005. A genome-wide screen identifies a Bordetella type III secretion effector and candidate effectors in other species. Mol, Microbiol. 58:267-79.

Petnicki-Ocwieja, T., van Dijk, K., and Alfano, J. R. 2005. The hrpK operon of Pseudomonas syringae pv. tomato DC3000 encodes two proteins secreted by the type III (Hrp) protein secretion system: HopB1 and HrpK, a putative type III translocator. J. Bacteriol. 187:649-663.

Petnicki-Ocwieja, T., Schneider, D. J., Tam, V. C., Chancey, S. T., Shan, L., Jamir, Y., Schechter, L. M., Buell, C. R., Tang, X., Collmer, A., and Alfano, J. R. 2002. Genomewide identification of proteins secreted by the Hrp type III protein secretion system of Pseudomonas syringae pv. tomato DC3000. Proc. Natl. Acad. Sci. U.S.A. 99:7652-7657.

Reuber, T. L., and Ausubel, F. M. 1996. Isolation of Arabidopsis genes that differentiate between resistance responses mediated by the RPS 2 and RPM1 disease resistance genes. Plant Cell 8:241-249.

Ritter, C., and Dangl, J. L. 1996. Interference between two specific pathogen recognition events mediated by distinct plant disease resistance genes. Plant Cell 8:251-257.

Roden, J. A., Belt, B., Ross, J. B., Tachibana, T., Vargas, J., and Mudgett, M. B. 2004. A genetic screen to isolate type III effectors translocated into pepper cells during Xanthomonas infection. Proc. Natl. Acad. Sci. U.S.A. 101:16624-16629.

Rohmer, L., Kjemtrup, S., Marchesini, P., and Dangl, J. L. 2003. Nucleotide sequence, functional characterization and evolution of $\mathrm{pFKN}$, a virulence plasmid in Pseudomonas syringae pathovar maculicola. Mol. Microbiol. 47:1545-62.

Ronald, P. C., Salmeron, J. M., Carland, F. M., and Staskawicz, B. J. 1992. The cloned avirulence gene avrPto induces disease resistance in tomato cultivars containing the Pto resistance gene. J. Bacteriol. 174:16041611.

Sambrook, J., Fritsch, E. F., and Maniatis, T. 1989. Molecular Cloning: A Laboratory Manual, 2nd ed. Cold Spring Harbor Laboratory Press, Cold Spring Harbor, NY, U.S.A.

Schechter, L. M., Roberts, K. A., Jamir, Y., Alfano, J. R., and Collmer, A. 2004. Pseudomonas syringae type III secretion system targeting signals and novel effectors studied with a Cya translocation reporter. J. Bacteriol. 186:543-555.

Shan, L., Oh, H. S., Chen, J., Guo, M., Zhou, J., Alfano, J. R., Collmer, A., Jia, X., and Tang, X. 2004. The HopPtoF locus of Pseudomonas syringae pv. tomato DC3000 encodes a type III chaperone and a cognate effector. Mol. Plant-Microbe Interact. 17:447-455.

Sorg, J. A., Miller, N. C., and Schneewind, O. 2005. Substrate recognition of type III secretion machines-testing the RNA signal hypothesis. Cell Microbiol. 7:1217-25.

Sory, M.-P., and Cornelis, G. R. 1994. Translocation of a hybrid YopE-adenylate cyclase from Yersinia enterocolitica into HeLa cells. Mol. Microbiol. 14:583-594.

Stevens, C., Bennett, M. A., Athanassopoulos, E., Tsiamis, G., Taylor, J. D., and Mansfield, J. W. 1998. Sequence variations in alleles of the avirulence gene avrPphE.R2 from Pseudomonas syringae pv. phaseolicola lead to loss of recognition of the AvrPphE protein within bean cells and a gain in cultivar-specific virulence. Mol. Microbiol. 29:165-1677.

Subtil, A., Delevoye, C., Balana, M. E., Tastevin, L., Perrinet, S., and Dautry-Varsat, A. 2005. A directed screen for chlamydial proteins secreted by a type III mechanism identifies a translocated protein and numerous other new candidates. Mol. Microbiol. 56:1636-1647.

van Dijk, K., Fouts, D. E., Rehm, A. H., Hill, A. R., Collmer, A., and Alfano, J. R. 1999. The Avr (effector) proteins HrmA (HopPsyA) and AvrPto are secreted in culture from Pseudomonas syringae pathovars via the Hrp (type III) protein secretion system in a temperature- and pH-sensitive manner. J. Bacteriol. 181:4790-4797.

Vencato, M., Tian, T., Alfano, J. R., Buell, C. R., Cartinhour, S., DeClerck, J., Guttman, D. S., Joardar, V., Lindeberg, M., Bronstein, P. A., Mansfield, J., Myers, C. R., Collmer, A., and Schneider, D. J. 2006. Bioinformatics-enabled identification of the HrpL regulon and type III secretion system effector proteins of Pseudomonas syringae pv. phaseolicola 1448A. Mol. Plant-Microbe Interact. 19:1193-1206.

Vinatzer, B. A., Jelenska, J., and Greenberg, J. T. 2005. Bioinformatics correctly identifies many type III secretion substrates in the plant pathogen Pseudomonas syringae and the biocontrol isolate P. fluorescens SBW25. Mol. Plant Microbe Interact. 18:877-888.

Zwiesler-Vollick, J., Plovanich-Jones, A. E., Nomura, K., Brandyopadhyay, S., Joardar, V., Kunkel, B. N., and He, S. Y. 2002. Identification of novel hrp-regulated genes through functional genomic analysis of the Pseudomonas syringae pv. tomato DC3000 genome. Mol. Microbiol. 45:12071218 .

\section{AUTHOR-RECOMMENDED INTERNET RESOURCE}

Pseudomonas-Plant Interaction website: pseudomonas-syringae.org 